Submitted, accepted and published by:

Fuel Processing Technology (2013) Vol. 109, pp. 57-69

\title{
Performance of a bauxite waste as oxygen-carrier for chemical- looping combustion using coal as fuel
}

T. Mendiara*, P. Gayán, A. Abad, L. F. de Diego, F. García-Labiano, J. Adánez

Department of Energy and Environment, Instituto de Carboquímica (CSIC)

Miguel Luesma Castán 4, 50018, Zaragoza, Spain

tmendiara@icb.csic.es

* Corresponding author:

Phone: + 34976733 977;

Fax: +34976733318 


\section{Abstract}

In the recently developed Chemical-Looping Combustion (CLC) technology, the oxygen needed for the oxidation of the fuel is provided by an oxygen-carrier. Today, there is an increasing interest on CLC application to solid fuels, especially coal. One of the possibilities to process coal in a CLC system is the in situ gasification and subsequent combustion of the product gases ( $i G$-CLC). Potential CLC oxygen-carriers should comply with some chemical and mechanical requirements but it would be interesting that the carrier is as inexpensive as possible, as some losses are expected accompanying the coal ashes. In the present work, a residue from alumina production mainly constituted by $\mathrm{Fe}_{2} \mathrm{O}_{3}$ has been tested as oxygencarrier in CLC of coal. Batch experiments were carried out in a fluidized-bed reactor using a bituminous coal as fuel. The effect of operating conditions, such as temperature and gasification agent on the char conversion and combustion efficiency of gasification products were evaluated. Several $\mathrm{H}_{2} \mathrm{O} / \mathrm{CO}_{2}$ mixtures were tested as gasifying agents. After 50 hours of cycling operation in a batch fluidized bed, no defluidization or agglomeration problems were observed. A gain in the reactivity of the bauxite waste was observed with the number of redox cycles. The carrier showed high combustion efficiencies at all temperatures tested meaning that the bauxite waste was capable of burning the gases generated during the gasification of the char. The percentage of $\mathrm{CO}_{2}$ in the feeding should be limited in order to maintain high gasification rates and combustion efficiencies. The present results indicate that this bauxite waste is a promising oxygen-carrier for the $i \mathrm{G}-\mathrm{CLC}$ of coal.

Keywords: chemical-looping combustion, coal, $\mathrm{CO}_{2}$ capture, red mud, bauxite waste, char 


\section{Introduction}

The world electricity demand is expected to grow more strongly in the coming years than any other final form of energy [1]. Today, the fuel of choice for electricity generation is often coal and it is also expected to remain an increasingly important fuel in the near future while the shares of renewables expand [2]. The evidences of global warming have focus attention on the $\mathrm{CO}_{2}$ emissions to the atmosphere from the combustion of fossil fuels. Both the emissions and the coal share of the emissions are expected to increase toward 2030 for the world as a whole [1]. Therefore, many research efforts are focused on the $\mathrm{CO}_{2}$ emission minimization in coal combustion. Since electricity generation plants are stationary, they are considered as an easier target for reducing $\mathrm{CO}_{2}$ through Carbon Capture and Storage CCS [3].

$\mathrm{CCS}$ is a process consisting in the separation of $\mathrm{CO}_{2}$ from industrial and energy-related sources, its transportation to a storage location and long-term isolation from the atmosphere. One of the challenges for the success of CSS is to reduce the costs related to $\mathrm{CO}_{2}$ capture [4]. The Chemical-Looping Combustion (CLC) technology allows combustion with inherent $\mathrm{CO}_{2}$ separation at low cost [5]. The main idea of CLC is to split combustion of a carbonaceous fuel into separate oxidation and reduction reactions by introducing a suitable metal oxide as an oxygen-carrier to circulate between two reactors called fuel- and air-reactors.

The feasibility of this process has been demonstrated in different CLC prototypes up to 140 $\mathrm{kW}_{\text {th }}$ using gaseous fuels and oxygen-carriers based on nickel, cobalt, manganese and copper oxides [6-12]. In the recent years, CLC applied to solid fuels has gained great interest [13]. Up to date, two approaches have been proposed for CLC with coal. In the first one (syngasCLC), coal gasification is carried out and the syngas produced subsequently introduced in the 
CLC system [13-15]. The second possibility (solid fuelled-CLC) is the direct feeding of the coal to the reactor where it may be either gasified by $\mathrm{H}_{2} \mathrm{O}$ or $\mathrm{CO}_{2}$, i.e in situ GasificationChemical-Looping Combustion (iG-CLC) [16], or it will be burned with gaseous oxygen released by the oxygen-carrier, i.e. Chemical-Looping with Oxygen Uncoupling (CLOU) [17].

The reaction between fuel and oxygen-carrier takes place in the fuel-reactor where the oxygen-carrier is reduced while the fuel is oxidized. As shown in Figure 1, in the $i \mathrm{G}$-CLC, coal is physically mixed with the oxygen-carrier in the fuel-reactor and the carrier reacts with the gaseous products of coal gasification, where $\mathrm{H}_{2}$ and $\mathrm{CO}$ are main components. The gasification process has been identified as the controlling step in the $i \mathrm{G}-\mathrm{CLC}$ concept [18]. Reactions (1)-(4) summarize the processes taking place in the fuel-reactor:

$$
\begin{aligned}
& \text { Coal } \rightarrow \text { volatiles }+ \text { char } \\
& \text { Char }+\mathrm{H}_{2} \mathrm{O} \rightarrow \mathrm{H}_{2}+\mathrm{CO} \\
& \text { Char }+\mathrm{CO}_{2} \rightarrow 2 \mathrm{CO} \\
& \mathrm{H}_{2}, \mathrm{CO} \text {, volatiles }+\mathrm{n} \mathrm{M}_{\mathrm{x}} \mathrm{O}_{\mathrm{y}} \rightarrow \mathrm{CO}_{2}+\mathrm{H}_{2} \mathrm{O}+\mathrm{n} \mathrm{M}_{\mathrm{x}} \mathrm{O}_{\mathrm{y}-1}
\end{aligned}
$$

The product gas from the fuel-reactor consists of $\mathrm{CO}_{2}$ and $\mathrm{H}_{2} \mathrm{O}$. Water can be easily separated by condensation leading to a high $\mathrm{CO}_{2}$ concentrated stream, ready for compression and sequestration, without additional costs or energy penalties for gas separation.

In the air-reactor, the oxygen-carrier is regenerated following reaction (5):

$$
\mathrm{M}_{\mathrm{x}} \mathrm{O}_{\mathrm{y}-1}+1 / 2 \mathrm{O}_{2} \rightarrow \mathrm{M}_{\mathrm{x}} \mathrm{O}_{\mathrm{y}}
$$


The net chemical reaction and combustion enthalpy is the same as in a conventional combustion. The circulation rate of the solid material between the reactors and the average solids residence time in each reactor control the heat balance and the temperature levels in each reactor.

The efficiency of char gasification in the fuel-reactor and the separation of ash from the oxygen-carrier seem to be key factors for the development of this process. Unconverted char leaving the fuel-reactor will burn when exposed to air in the air-reactor, according to equation (6) and therefore decreasing the carbon capture efficiency.

$\mathrm{C}+\mathrm{O}_{2} \rightarrow \mathrm{CO}_{2}$

One option to reduce the char amount reaching the air-reactor is to increase the residence time of char particles in the fuel-reactor. In order to increase the residence time without excessively increasing the reactor size, the separation of char from oxygen-carrier particles and recirculation to the fuel-reactor by means of a carbon separation system has been proposed as shown in Figure 1 [16].

Moreover, the development of appropriate oxygen-carriers will determine the success of the CLC technology. Besides the common chemical and mechanical properties demanded for an oxygen-carrier, in CLC of coal it is especially interesting to find inexpensive oxygen-carriers, as there might be losses of material during ash separation. Lately, different Fe-based ores [19$34]$ and industrial by-products [19,26,35] have been evaluated as oxygen-carriers for $i \mathrm{G}$ CLC. Among the different Fe-based oxygen-carriers tested, the use of the natural ore ilmenite has been extensively analyzed. Ilmenite is a natural mineral composed of $\mathrm{FeTiO}_{3}\left(\mathrm{FeO} \cdot \mathrm{TiO}_{2}\right)$. 
Through the different studies, ilmenite showed highly reactive to $\mathrm{CO}$ and $\mathrm{H}_{2}$ but moderate conversion of $\mathrm{CH}_{4}[20,36]$. Good mechanical stability and fluidizing properties for this material have also been observed. Several studies in different experimental configurations have analyzed the main variables influencing the process. Leion et al. [27] observed that the coal gasification reaction was slow when compared to the reaction of the oxygen-carrier with the gasification products $\left(\mathrm{CO}\right.$ and $\left.\mathrm{H}_{2}\right)$. Actually, other batch fluidized-bed studies with coal also pointed to a high reactivity of different Fe-based oxygen-carriers to $\mathrm{H}_{2}$ and $\mathrm{CO}$ generated in coal gasification [21,37-38]. Therefore, the gasification of the fuel can be considered as the limiting step of the process $[21,27]$. Steam was preferred as gasification agent to $\mathrm{CO}_{2}$, since the gasification rate was higher. The resulting combustion efficiency was therefore higher when gasifying with high $\mathrm{H}_{2} \mathrm{O} / \mathrm{CO}_{2}$ molar ratio [21]. Besides these works, the $i \mathrm{G}-\mathrm{CLC}$ concept using low-cost Fe-based materials has been recently proven during continuous operation in CLC units ranging from $500 \mathrm{~W}_{\text {th }}$ to $10 \mathrm{~kW}_{\text {th }}[22-25,30-31,39-40]$. Good performance with different Fe-based carriers was described. $\mathrm{CO}_{2}$ capture efficiencies ranged $60-96 \%$ depending on the reactivity of the solid fuel used.

This work focuses on the evaluation of a Fe-based industrial residue as oxygen-carrier for CLC of coal, as the use of residues represents an interesting advantage both from the environmental point of view and the economy of the process. The residue used is an industrial by-product in the alumina production containing a high amount of iron. It is obtained after bauxite digestion in the Bayer process and is generated in a very large quantity, around 55 to $70 \%$ of the bauxite processed [41-43]. The active material in the bauxite waste is $\mathrm{Fe}_{2} \mathrm{O}_{3}$ and it is present mainly together with $\mathrm{Al}_{2} \mathrm{O}_{3}$. In previous studies by our research group, the behaviour of this bauxite waste for CLC with different gaseous fuels was analyzed [44]. The bauxite waste showed a good performance in the combustion of syngas [44]. 
Regarding the use of the bauxite waste in coal combustion, the performance of the carrier was evaluated in two consecutive steps. First, the reactivity of the potential oxygen-carrier to the main gases generated in coal gasification was evaluated in a recent work [35]. The bauxite waste reacted faster with $\mathrm{H}_{2}$ than with $\mathrm{CO}$ and $\mathrm{CH}_{4}$. Nevertheless, the reaction rates observed were similar to those of a synthetic $\mathrm{Fe}_{2} \mathrm{O}_{3} / \mathrm{Al}_{2} \mathrm{O}_{3}$ oxygen-carrier [45] and higher than the corresponding values found for ilmenite [20]. Besides, the fluid dynamics properties of the bauxite waste were adequate for the operation in a fluidized-bed. Now in this work, the reaction of the bauxite waste with the char formed during coal gasification was tackled and analyzed. The effect of operating conditions, such as temperature $\left(900-980^{\circ} \mathrm{C}\right)$ and gasification agent $\left(\mathrm{H}_{2} \mathrm{O}, \mathrm{CO}_{2}\right.$ or $\mathrm{H}_{2} \mathrm{O} / \mathrm{CO}_{2}$ mixtures $)$ on the char conversion and combustion efficiency of gasification products was analyzed in a batch fluidized-bed reactor. The activation of the bauxite waste samples under several reducing/oxidizing cycles using char will be also investigated.

\section{Experimental}

\subsection{Materials used}

The Fe-based oxygen-carrier used in this work corresponds to the sand fraction obtained in the alumina production via de Bayer process. In this process, the majority of the aluminumcontaining species in the ore are dissolved leaving an insoluble residue. In the clarification step, the sand fraction (particles over $150 \mu \mathrm{m}$ ) is separated and the rest sent to sedimentation tanks, where the smallest particle fraction (red mud) is deposited. This Fe-based sand fraction was supplied by Alcoa Europe-Alúmina Española S.A. It will be referred to as bauxite waste throughout this paper. The bauxite waste was dried at room temperature for 72 hours and 
then sieved to the desired size $(150-300 \mu \mathrm{m})$. Prior to its use, the dried sample was calcined at $1200^{\circ} \mathrm{C}$ during $18 \mathrm{~h}$ to ensure complete oxidation of the sample and to increase the mechanical strength.

The main chemical and physical properties of the calcined material are shown in Table 1 . The active $\mathrm{Fe}_{2} \mathrm{O}_{3}$ content was determined in a TGA using $15 \% \mathrm{H}_{2}$ at $950^{\circ} \mathrm{C}$, and therefore, this percentage corresponds to the amount of iron reducible species, which are the species to take part in the chemical-looping process. The identification of crystalline chemical species was carried out by powder X-ray diffraction (XRD) patterns acquired in an X-ray diffractometer Bruker AXS D8ADVANCE using Ni-filtered $\mathrm{Cu} \mathrm{K \alpha}$ radiation equipped with a graphite monochromator. The XRD analysis of the calcined sample confirmed that $\mathrm{Fe}_{2} \mathrm{O}_{3}$ and $\beta-\mathrm{Al}_{2} \mathrm{O}_{3}$ were the major components. The composition of the sample was determined by an ICP Jobin Ybon 2000 apparatus. The weight percentages obtained were $75.2 \% \mathrm{Fe}_{2} \mathrm{O}_{3}, 13.6 \% \mathrm{Al}_{2} \mathrm{O}_{3}$, $6.5 \% \mathrm{TiO}_{2}, 2.0 \% \mathrm{SiO}_{2}, 2.3 \% \mathrm{Na}_{2} \mathrm{O}$ and $0.4 \% \mathrm{CaO}$. The force needed to fracture a particle was determined using a Shimpo FGN-5 crushing strength apparatus. The value for the mechanical strength was estimated as the average of 20 different measurements on randomly selected particles. The values obtained for the calcined samples resulted adequate for operating in a circulating fluidized-bed (CFB) [46]. Particle porosity was measured by $\mathrm{Hg}$ intrusion in a Quantachrome PoreMaster 33. The real density of the particles was measured with a Micromeritics AccuPyc II 1340 helium picnometer. Brunauer-Emmett-Teller (BET) surface area value was measured and a low value was obtained.

Samples before and after reaction were analyzed using a scanning electron microscope SEM EDX Hitachi S-3400 N equipped with an EDX analyzer Röntec XFlash de Si(Li). 
The oxygen transport capacity, $R_{O}$, is defined as the mass fraction that can be used in the oxygen transfer.

$$
R_{O}=\frac{m_{o}-m_{r}}{m_{o}}
$$

where $m_{o}$ and $m_{r}$ are the mass of fully oxidized and reduced bauxite waste sample, respectively.

The value of the oxygen transport capacity, $R_{O}$, depends on the final oxidation state after reduction. Although iron compounds have different oxidation states $\left(\mathrm{Fe}_{2} \mathrm{O}_{3}-\mathrm{Fe}_{3} \mathrm{O}_{4}-\mathrm{FeO}-\mathrm{Fe}\right)$, only the transformation from hematite $\left(\mathrm{Fe}_{2} \mathrm{O}_{3}\right)$ to magnetite $\left(\mathrm{Fe}_{3} \mathrm{O}_{4}\right)$ may be applicable for industrial CLC systems. Further reduction to $\mathrm{FeO}$ would decrease the $\mathrm{CO}_{2}$ purity obtained in the fuel-reactor due to the increase of $\mathrm{CO}$ and $\mathrm{H}_{2}$ concentrations in the equilibrium [45]. Besides, it has been demonstrated that the reduction to $\mathrm{FeO}$ may lead to agglomeration in the subsequent oxidation process $[36,47]$. Therefore, the value of the oxygen transport capacity in this case, $R_{O C}$, corresponds to the transformation to only $\mathrm{Fe}_{3} \mathrm{O}_{4}$.

As mentioned before, char from a bituminous South African coal was used as fuel in the experiments. Char was produced when around $300 \mathrm{~g}$ of coal particles sized 200-300 $\mu \mathrm{m}$ were devolatilizated in a fluidized-bed reactor using $\mathrm{N}_{2}$ as fluidizing agent. The bed operated in the bubbling bed regime through the whole experiment in order to avoid elutration of particles. Temperature was increased from room temperature to $900^{\circ} \mathrm{C}$ using a heating rate of $20^{\circ} \mathrm{C} / \mathrm{min}$. Once the temperature was reached, the heat supply was stopped and the sample was cooled down in nitrogen. Table 2 shows the proximate and ultimate analyses of the coal and the char obtained. The yield to char was around $70 \mathrm{wt} . \%$. 


\subsection{Thermogravimetric apparatus (TGA)}

The reactivity of the bauxite waste was analyzed in a thermogravimetric apparatus (TGA) CI Electronics type operating at atmospheric pressure. A detailed description of this apparatus has been presented before [48]. In all the experiments, $50 \mathrm{mg}$ of oxygen carrier particles were loaded on a platinum basket. The system was heated in nitrogen up to the desired temperature. To analyze the activation process of this material, different samples were extracted from the batch fluidized-bed reactor after sucessive cycles and analyzed in the TGA. Depending on the ratio $\mathrm{H}_{2} \mathrm{O} / \mathrm{H}_{2}$, the reduction of $\mathrm{Fe}_{2} \mathrm{O}_{3}$ can finish in one of the above mentioned products $\left(\mathrm{Fe}_{2} \mathrm{O}_{3}-\mathrm{Fe}_{3} \mathrm{O}_{4}-\mathrm{FeO}-\mathrm{Fe}\right)$. In order to obtain $\mathrm{Fe}_{3} \mathrm{O}_{4}$ as stable reduced phase, the $\mathrm{H}_{2} \mathrm{O} / \mathrm{H}_{2}$ ratio must be higher than 2.8 [45]. Therefore, the reducing mixture employed was $5 \% \mathrm{H}_{2}+40 \% \mathrm{H}_{2} \mathrm{O}$, with nitrogen to balance. For steam addition, the gas flow was bubbled through a saturator containing water at the required saturation temperature. All the experiments were carried out at $950^{\circ} \mathrm{C}$. During the solid oxidizing period, the particles were regenerated in air at the same temperature as the reduction took place.

The conversion for the reduction, $X_{r}$, and oxidation, $X_{o}$, of the oxygen carrier were calculated from the mass variations registered in TGA as:

$$
\begin{aligned}
& X_{r}=\frac{m_{o}-m}{m_{o}-m_{r}}=\frac{m_{o}-m}{R_{O C} m_{o}} \\
& X_{o}=1-X_{r}=\frac{m-m_{r}}{R_{O C} m_{o}}
\end{aligned}
$$


where $m$ is the instantaneous mass of the sample. For the calculation of the conversion, a value of $R_{O C}=2.4 \%$ was considered in all cases.

\subsection{Batch fluidized-bed (FB)}

Figure 2 presents the scheme of the experimental setup which has also been used in previous works of our research group [21]. The bauxite waste sample was placed inside the fluidizedbed reactor (FB). The amount loaded was $400 \mathrm{~g}$. The FB reactor was $0.055 \mathrm{~m} \mathrm{I.D} \mathrm{and} 0.7 \mathrm{~m}$ in length, with a pre-heating zone under the distributor, and was located inside an electricallyheated furnace. Both temperature and pressure drop in the bed were measured. The changes in the pressure drop help to detect possible agglomeration problems in the bed.

Gases were fed at the bottom of the reactor. By means of a three-way-valve, it was possible to switch between water vapour/ $\mathrm{CO}_{2}$, nitrogen and air so that the sample was sequentially exposed to reducing, purge and oxidation periods. Water vapour was produced by heating up in an evaporator the corresponding water flow supplied by a peristaltic pump.

Air was supplied as fluidizing agent while heating up to the desired temperature. Once the reaction temperature was reached, a nitrogen flow purged the system before the experiment started. During the reducing periods, char was used as fuel whereas the reactor was fluidized with water vapour, $\mathrm{CO}_{2}$ or water vapour/ $\mathrm{CO}_{2}$ mixtures, which also acted as gasification agents. The coal char was fed at about 5-6 cm below the upper level of the fluidizing particles using a fuel chute. As it can be seen in Figure 2, the char particles were placed in a deposit in the upper part of the chute (v1) and overpresussurized with nitrogen (v2). The amount introduced was in a range of 6.1-9.2 molar $\mathrm{O} / \mathrm{C}$ ratio, which corresponds to 1-1.5 $\mathrm{g}$ of char. 
This amount was estimated as the highest amount to be introduced with no major fuel entrainment. At the beginning of the experiment, the valve connecting the deposit with the fuel chute (v3) was quickly opened and closed so that the char particles were introduced. This procedure ensures an efficient char feeding inside the oxygen-carrier bed, favouring the mixing between the fuel and solid material used as bed. The reducing period was considered finished when char gasification was complete. After every reducing period, the oxygen carrier particles were fully re-oxidized with air before starting a new cycle. Between the reducing and oxidizing periods a nitrogen flow purged the system during 2 min to avoid mixing gaseous atmospheres. The total flow used was $200 \mathrm{~L}_{\mathrm{N}} / \mathrm{h}$, which corresponds to a gas velocity of $0.1 \mathrm{~m} / \mathrm{s}$ at $900^{\circ} \mathrm{C}$ in the reactor.

The product gas leaving the reactor was conducted to a filter that retained the solids that may elutriate during reaction. Before entering the analyzers, the product gas flowed through a condenser to eliminate water prior to analysis. At this point $90 \mathrm{~L}_{\mathrm{N}} / \mathrm{h}$ nitrogen flow was introduced to ensure a continuous dry gas flow feeding the analyzers. The dry gases concentration were continuously registered and collected with a data logger connected to a computer. $\mathrm{CO}, \mathrm{CO}_{2}$ and $\mathrm{CH}_{4}$ dry basis concentrations were determined using non-dispersive infrared analysis (NDIR) and $\mathrm{H}_{2}$ by thermal gas conductivity. The $\mathrm{O}_{2}$ concentration was determined in a paramagnetic analyzer.

The effect of temperature and fluidization gas composition on the reaction rates of gasification and subsequent combustion of gasification products was analyzed, as well as the role of bauxite waste during char gasification. The temperature was varied in the $900-980^{\circ} \mathrm{C}$ range. Different $\mathrm{H}_{2} \mathrm{O}: \mathrm{CO}_{2}$ molar ratios were used $(0: 100,10: 90,30: 70 ; 100: 0)$. The same batch of particles was exposed to a total number of 40 reduction/oxidation cycles (50 hours). 
The morphology and reactivity of the bauxite waste samples extracted at different operation times were also evaluated using different techniques.

\subsection{Data evaluation}

Mass balances to carbon, hydrogen and oxygen were done considering the $\mathrm{CO}, \mathrm{CO}_{2}, \mathrm{H}_{2}, \mathrm{H}_{2} \mathrm{O}$ and $\mathrm{CH}_{4}$ flows in every experiment. From the results obtained, the performance of bauxite waste during char gasification and combustion of gasification products was evaluated. The molar gas flow of each component exiting the fuel-reactor, $F_{i}$, is calculated as:

$F_{i}=F_{\text {out }} \cdot y_{i}$

where $y_{i}$ is the molar fraction of the component $i\left(\mathrm{CO}_{2}, \mathrm{CO}, \mathrm{H}_{2}\right.$ or $\left.\mathrm{CH}_{4}\right)$ in the product gas.

The total dry basis outlet flow, $F_{\text {out }}$, can be calculated by using the downstream introduced $\mathrm{N}_{2}$ flow, $F_{N_{2}}$ :

$$
F_{\text {out }}=\frac{F_{N_{2}}}{\left(1-\sum_{i} y_{i}\right)}
$$

The rate of char conversion, $r_{C}(t)$, was calculated from a carbon balance to gaseous species in the reactor. Methane was not detected in any case and therefore was not considered in the balance. 
$r_{C}(t)=\left(y_{\mathrm{CO}_{2}}+y_{\mathrm{CO}}\right) \cdot F_{\text {out }}-F_{\mathrm{CO}_{2}, \text { in }}$

The evolution of char conversion, $X_{\text {char }}$, with time can be calculated by integrating equation (12).

$$
X_{\text {char }}(t)=\frac{\int_{0}^{t} r_{C}(t) \cdot d t}{N_{C, \text { char }}}
$$

where $N_{C, \text { char }}$ are the moles of carbon fed into the reactor.

The instantaneous rate of conversion of the char, $r_{C, \text { inst }}$, is calculated as the rate of gasification per the amount of non-gasified carbon in the reactor.

$$
r_{C, \text { inst }}(t)=\frac{r_{C}(t)}{N_{C, \text { char }}-\int_{0}^{t} r_{C}(t) \cdot d t}
$$

The time to convert $95 \%$ of the char present in the bed, $\left(t_{95}\right)$, was determined, as an estimation of the residence time to mostly convert the char in the reactor $[21,27,38]$. In order to calculate this value it was assumed that the gasification reaction can be represented using the homogeneous model:

$$
r_{C, \text { inst }}=\frac{1}{m_{\text {char }}} \cdot \frac{d m_{\text {char }}}{d t}=\frac{1}{1-X_{\text {char }}} \frac{d X_{\text {char }}}{d t}
$$

From equation (15), the value for $t_{95}$ can be calculated as: 
$t_{95}=-\frac{1}{r_{C, i n s t}} \ln (1-0.95)$

The rate of oxygen transferred from the oxygen-carrier to the fuel gas, $r_{O_{\text {red }}}(t)$, can be calculated through the oxygen balance:

$r_{O_{\text {red }}}(t)=F_{O, \text { out }}-F_{O, \text { in }}=\left[F_{\text {out }} \cdot\left(2 y_{\mathrm{CO}_{2}}+y_{\mathrm{CO}}\right)-2 F_{\mathrm{CO}_{2}, \text { in }}\right]+\left[F_{\mathrm{H}_{2} \mathrm{O}, \text { out }}-F_{\mathrm{H}_{2} \mathrm{O}, \text { in }}\right]$

In equation (17) the amount of $\mathrm{CO}_{2}$ fed to the reactor is subtracted in order to calculate the amount of $\mathrm{CO}_{2}$ generated. Several assumptions were made in order to simplify the equation. According to the values presented in Table 2 the amount of hydrogen and oxygen present in the fuel is very low and therefore it was not considered in the mass balances The flow of water at the reactor exit was calculated assuming that the flow of hydrogen either in $\mathrm{H}_{2}$ or $\mathrm{H}_{2} \mathrm{O}$ comes only from introduced steam, $F_{\mathrm{H}_{2} \mathrm{O} \text {,in }}$, and neglecting hydrogen in char moisture.

$$
F_{\mathrm{H}_{2} \mathrm{O}, \text { out }}=F_{\mathrm{H}_{2} \mathrm{O}, \text { in }}-F_{\text {out }} \cdot y_{\mathrm{H}_{2}}
$$

Including all the previous assumptions in equation (17), it is reduced to:

$$
r_{\mathrm{O}_{\text {red }}}(t)=F_{\text {out }} \cdot\left(2 y_{\mathrm{CO}_{2}}+y_{\mathrm{CO}}-y_{\mathrm{H}_{2}}\right)-2 F_{\mathrm{CO}_{2}, \text { in }}
$$

The oxygen carrier conversion in the fluidized-bed was analyzed by the oxidation conversion, $X_{O}$, during both reducing and oxidizing periods. Thus, during reduction the oxidation conversion can be calculated from the integration of $r_{O}(t)$ with time as: 


$$
X_{o}(t)=1-\frac{1}{N_{O, b w}} \int_{0}^{t} r_{O}(t) \cdot d t
$$

where $N_{O, b w}$ are the moles of oxygen in bauxite waste active for CLC process:

$$
N_{O, b w}=\frac{m_{O C} \cdot R_{O C}}{M_{O}}
$$

where $\mathrm{M}_{\mathrm{O}}$ is the oxygen molar weight.

During the oxidation period, the oxygen-carrier was re-oxidized in air. The rate of oxygen transfer from air to the reduced solid is calculated in this case as:

$$
r_{O_{\text {oxi }}}(t)=F_{O, \text { out }}-F_{O, \text { in }}=2 \cdot\left(F_{O_{2, \text { in }}}-F_{O_{2, \text { out }}}\right)
$$

and the oxygen-carrier conversion during oxidation is calculated as:

$$
X_{o}(t)=X_{f, r e d}+\frac{1}{N_{O, b w}} \int_{0}^{t} r_{O_{o x i}}(t) \cdot d t
$$

where $X_{f, r e d}$ is the conversion reached by the bauxite waste in the previous reduction.

Finally, the conversion of gasification products, i.e. $\mathrm{CO}$ and $\mathrm{H}_{2}$, to $\mathrm{CO}_{2}$ and $\mathrm{H}_{2} \mathrm{O}$ by reaction with the bauxite waste particles was evaluated using the combustion efficiency, $\eta_{\mathrm{C}}$. The combustion efficiency is defined as the oxygen gained by the fuel for its oxidation divided per the oxygen needed to fully oxidize the fuel. 


$$
\eta_{C}(t)=\frac{r_{O_{r e d}}(t)}{2 r_{C}(t)}
$$

\section{Results and Discussion}

\subsection{Activation of the bauxite waste sample}

The activation process of minerals or industrial residues have been previously reported in the literature both using gaseous [19-20,26,36,49,50] and solid fuels [21]. In this sense, the activation of the bauxite waste sample with gaseous fuels was evidenced in a previous work [35]. In this work, the activation of the bauxite waste using coal char as fuel was first analyzed in the batch fluidized-bed reactor. The experiments were performed at $900^{\circ} \mathrm{C}$ and using steam as fluidizing/gasifying agent. In each reducing cycle, two loads of $1 \mathrm{~g}$ char were added so that the variation of the solid conversion achieved was about 0.4 . Figure 3 shows the product gas concentration (wet basis and nitrogen free) at the exit of the reactor together with the solid conversion evolution in a typical reduction cycle using two consecutive loads of char and steam as gasifying agent. The reduction step was considered finished when the char was completely gasified and therefore no $\mathrm{CO}$ or $\mathrm{CO}_{2}$ were detected in the outlet stream.

In Figure 3, after the addition of the first char load, the $\mathrm{CO}_{2}$ concentration increases to a maximum value of $3 \%$ and then decreases as the amount of char in the bed also decreases. No $\mathrm{CO}$ or $\mathrm{H}_{2}$ were detected during this first reduction, indicating that the material was capable of completely burning all the gases generated during char gasification. The variation of oxygen carrier conversion during this first period is 0.18 . A second char load was added after the gasification of the first one was completed. Again, a similar maximum in $\mathrm{CO}_{2}$ concentration 
was observed and then the value of the concentration decreased as the char was depleted and no $\mathrm{CO}$ or $\mathrm{H}_{2}$ were present. The variation of the oxygen carrier conversion increased up to a final value of 0.36 .

After the reduction period, the gaseous atmosphere was switched to nitrogen for two minutes. Then, the bauxite waste was re-oxidized using air at the same temperature used during reduction. During the first stages of oxidation, all the oxygen was consumed due to the high reactivity of the bauxite waste material to oxygen. After that, the oxygen concentration increased up to the initial value. No $\mathrm{CO}$ or $\mathrm{CO}_{2}$ were detected during the oxidation, meaning that no char remained in the bed.

This experimental procedure was repeated during 23 consecutive cycles. As an activation of this material was found in a previous work in a TGA [35], it is believed that the activation of the sample takes place along these redox cycles. As shown in Figure 3, the bauxite waste sample was capable of burning all the gases generated during char gasification in all the cases and only $\mathrm{CO}_{2}$ was observed in the product gases. Therefore, it was not possible to determine from the gas product distribution if the activation process was underway. To analyze this activation process, some samples were extracted from the oxygen-carrier bed at different stages $\left(1^{\text {st }}, 4^{\text {th }}, 8^{\text {th }}, 15^{\text {th }}, 23^{\text {rd }}\right.$ cycles $)$. The reactivity of the samples extracted from the fluidized-bed at different cycles was analyzed instead in the TGA. Figure 4 shows the evolution of both the reduction $\left(X_{r}\right)$ and oxidation $\left(X_{o}\right)$ conversion with time for the experiments performed with the samples extracted from the FB reactor after the $1^{\text {st }}, 4^{\text {th }}, 8^{\text {th }}$, $15^{\text {th }}$ and $23^{\text {rd }} \mathrm{FB}$ cycle. The dashed lines are used as reference and they represent the reactivity obtained with a calcined and fully activated sample in the TGA. 
According to the conversion curves obtained in Figure 4, the bauxite waste increases its reactivity with the number of redox cycles performed with coal char, but after 23 redox cycles it has not reached fully activation both for reduction and oxidation reactions. The activation seems therefore to be slower than the previously observed when using gaseous fuels [35]. Using $\mathrm{H}_{2}$ as reducing agent, the sample could be considered fully activated after three cycles. In experiments with $\mathrm{CO}$ or $\mathrm{CH}_{4}$, full activation was observed after 20 cycles. These differences in the activation process were attributed to the different conversion degree obtained in each reducing cycle depending on the gas used. The higher the conversion obtained the fewer the cycles needed to fully activate the sample. A similar explanation would justify the results shown in Figure 4. The variation in the bauxite waste conversion achieved during cycling reduction with char was 0.4 at the most. Higher conversion degrees were obtained using gaseous fuels in the TGA [35]. Therefore, the activation of the sample using coal char would require more redox cycles. Figure 4 also shows with a dotted line the results corresponding to the bauxite waste sample extracted from the bed at the end of the experiments presented in this work $\left(40^{\text {th }}\right.$ cycle $)$. The conversion rate for reduction is slightly higher than the observed in the $23^{\text {rd }}$ cycle, but still very close to it. The gain in reactivity was higher for the oxidation reaction when the $23^{\text {rd }}$ and $40^{\text {th }}$ redox cycles are compared, but even in this case the conversion rate value is not the corresponding to a completely activated sample. The number of redox cycles performed in order to evaluate the effect of different operating parameters are not high enough in number to represent a significant progress in the further activation of the sample. Therefore, the experimental work here presented was carried out with a batch of partially activated sample, but maintaining roughly constant its reactivity.

\subsection{Char gasification in the presence of bauxite waste}


To determine the extent of the influence of the bauxite waste on the char gasification, the same experiment was performed using the bauxite waste and an inert bed, in this case silica sand. At $900^{\circ} \mathrm{C}$ and using steam as fluidizing agent, a load of $1.5 \mathrm{~g}$ of char was introduced into the bed. The experiment was considered finished when all the char was gasified. Figure 5 plots the $\mathrm{CO}, \mathrm{CO}_{2}$ and $\mathrm{H}_{2}$ molar flows generated during char gasification both in bauxite waste and in a silica sand bed together with the conversion evolution with time. Figure 5(A) shows that during char gasification using a silica sand bed, $\mathrm{H}_{2}$ and $\mathrm{CO}$ were produced in a $\mathrm{CO} / \mathrm{H}_{2}$ molar ratio which oscillated between 0.4-0.6 through the experiment. $\mathrm{CO}_{2}$ was also generated through the water-gas-shift reaction (WGS), although the equilibrium was not reach in these experimental conditions:

$\mathrm{CO}+\mathrm{H}_{2} \mathrm{O} \leftrightarrow \mathrm{CO}_{2}+\mathrm{H}_{2}$

The $\mathrm{CO}, \mathrm{CO}_{2}$ and $\mathrm{H}_{2}$ molar flow values decreased with the char conversion, as the char remaining in the bed also decreases. If bauxite waste is the material present in the bed, no $\mathrm{H}_{2}$ and $\mathrm{CO}$ were observed at the outlet of the reactor. Once generated, both $\mathrm{H}_{2}$ and $\mathrm{CO}$ react with the bauxite waste particles to produce $\mathrm{CO}_{2}$ and $\mathrm{H}_{2} \mathrm{O}$, which are the main gases present in the outlet stream. The $\mathrm{H}_{2}$ and $\mathrm{CO}$ removal from the gasification products reduced the inhibition effect that both gases, especially $\mathrm{H}_{2}$, could have on the gasification process [51]. Similar conclusions were reached before in previous studies using Fe-based oxygen carriers $[21,38,52]$. The decrease in the inhibition of char gasification can be observed in Figure 5 (B), where the char conversion evolution with time is represented for both sand and bauxite waste experiments. Considering the same reaction time, the char conversion values observed for the experiment using bauxite waste are around 2 times higher than those for the 
experiment with sand. Therefore, char gasification proceeds faster using bauxite waste as bed material.

\subsection{Dilution of the bauxite waste bed}

\subsubsection{Influence of temperature}

Some experiments were performed at different temperatures, namely 900,950 and $980^{\circ} \mathrm{C}$, with steam as gasifying agent. In this case, only one load of $1.5 \mathrm{~g}$ of char was introduced as fuel. In all the cases, the gaseous exit stream was again mainly composed of $\mathrm{CO}_{2}$ and steam. The bauxite waste was able to oxidize the $\mathrm{CO}$ and $\mathrm{H}_{2}$ generated during char gasification. The solid conversion reached in the reduction period was 0.22 in the experiment at $900^{\circ} \mathrm{C}$ and around 0.4 for the rest of the temperatures tested.

Figure 6 presents the values for the instantaneous rate of char conversion as a function of the char conversion at the different temperatures analyzed. The char conversion rate increased with temperature, confirming the findings of other authors which previously reported the notable influence of temperature on the gasification process [21,27,38]. The char conversion rate increased with char conversion at all temperatures tested. An average value for the char conversion rate could be calculated for the char conversion interval 0.1-0.7. The values are presented in Table 3. For comparison purposes, the values obtained using ilmenite as oxygen carrier are also presented [21]. The average values obtained for the bauxite waste are slightly higher than those obtained with activated ilmenite, although the value of the $\mathrm{O} / \mathrm{C}$ molar ratio was higher in the case of ilmenite. In the experiments with ilmenite, $\mathrm{CO}$ and $\mathrm{H}_{2}$ were registered in significant amounts in the gaseous products, while $\mathrm{CO}_{2}$ and $\mathrm{H}_{2} \mathrm{O}$ were the only 
products in the experiments with bauxite waste. Therefore, the lower rate values observed for ilmenite may be explained due to the gasification inhibition mainly caused by the hydrogen presence.

In the experiments above described, complete combustion of gasification products was reached when $400 \mathrm{~g}$ of bauxite waste were used. This means that complete combustion could be also reached with lower amount of solids. As the amount of char introduced could not be increased if entrainment of significant amounts of char should be avoided, the partially activated bed was diluted in alumina to reduce the $\mathrm{O} / \mathrm{C}$ molar ratio, so that the bauxite waste sample was not capable of burning all the gases generated during char gasification. In this way, the lower limit of the oxygen carrier inventory to get complete combustion can be evaluated. In order to analyze the char gasification and subsequent combustion processes, the total mass of the bed was maintained in $400 \mathrm{~g}$ and the dilution used was 50:50 (wt \%) bauxite waste in alumina, which corresponds to a $\mathrm{O} / \mathrm{C}$ ratio of 3.1.

The influence of temperature on the char gasification in the presence of bauxite waste was also tested with the 50:50 bauxite/alumina bed in the $900-980^{\circ} \mathrm{C}$ range. Figure 7 (A) shows the instantaneous rate of char conversion for the different temperatures tested using steam as fluidizing agent. For a certain char conversion interval, the conversion rate remained constant. This interval corresponds to $0.2-0.8$ at 900 and $950^{\circ} \mathrm{C}$ and $0.35-0.8$ for the highest temperature tested. The averaged rates of char conversion in these intervals, were $10.4 \% / \mathrm{min}$ at $900^{\mathrm{a}} \mathrm{C}, 27.4 \% / \mathrm{min}$ at $950^{\circ} \mathrm{C}$ and $41.9 \% / \mathrm{min}$ at $980^{\circ} \mathrm{C}$, so the char conversion rate was around four times higher at $980^{\circ} \mathrm{C}$ compared to the value at $900^{\circ} \mathrm{C}$. Table 3 shows the values obtained for the char conversion rates at different temperatures and compares them with the previous results from the non-diluted bed and with ilmenite. Using steam as gasifying agent, 
the averaged values obtained at $900^{\circ} \mathrm{C}$ were lower than those observed for the bauxite waste without dilution. This is attributed to the presence of small amounts of $\mathrm{CO}$ and specially $\mathrm{H}_{2}$, which act inhibiting the char gasification process. The values for the diluted bed are similar to those of ilmenite, where also $\mathrm{CO}$ an $\mathrm{H}_{2}$ were detected in the outlet gases, although the amount of available oxygen in the bauxite waste was around a third of that present with the ilmenite. Therefore, it can be concluded that there is not a significant effect of the amount of oxygen-carrier present in the fluidized-bed as long as $\mathrm{CO}$ and $\mathrm{H}_{2}$ concentrations in the gaseous atmosphere are low.

The influence of temperature on the char gasification was also evaluated using $\mathrm{CO}_{2}$ as fluidizing/gasifiying agent. The use of $\mathrm{CO}_{2}$ as gasifying agent in $i \mathrm{G}-\mathrm{CLC}$ processes could represent an interesting advantage from the energetic point of view, as it would contribute to decrease the energy penalty associated to steam generation. Experiments were performed at the same temperatures as the experiments using steam. Figure 7 (B) presents the evolution of the instantaneous rate of char conversion with the char conversion for the experiments at the three different temperatures. Note the different axis scale used compared to Figure 7 (A). The increase in temperature leads to an increase in the char conversion rate. The average values of the instantaneous char conversion rate calculated for the experiments using $\mathrm{CO}_{2}$ are included in Table 3. Average values were calculated for the different temperatures: $2.1 \% / \mathrm{min}$ at $900^{\circ} \mathrm{C}, 3.4 \% / \mathrm{min}$ at $950^{\circ} \mathrm{C}$ and $6.6 \% / \mathrm{min}$ at the highest temperature, $980^{\circ} \mathrm{C}$. The gasification of the South African coal char using $\mathrm{CO}_{2}$ is slower than using steam. The values observed using steam at the same conditions were 5-8 times those reported above. At the highest temperature tested, the values observed for ilmenite [21] and the bauxite waste become quite similar as can be observed in Table 3, despite the different amount of available oxygen in the bed. At lower temperatures the gasification rate was lower with bauxite waste because more 
unconverted $\mathrm{CO}$ was obtained than with ilmenite. To complete the char gasification comparison using different gasifying agents with the two Fe-based carriers, namely ilmenite and bauxite waste, the time to convert $95 \%$ of the char, $t_{95}$, is shown in Table 3 . The most favourable condition for a low residence time of the char particles in the reactor was the use of high temperatures. At $980^{\circ} \mathrm{C}$ with the diluted bauxite waste bed, $95 \%$ of the char fed was converted in 7.1 minutes using steam as gasifying agent while, if it is replaced by $\mathrm{CO}_{2}$, the char needs 45.4 minutes to reach the same conversion level. Besides, assuming an Arrhenius type temperature dependence of the gasification rate constant, the value for the apparent activation energy could be calculated, both for the experiments using steam or $\mathrm{CO}_{2}$ as fluidizing/gasification agents. For the experiments using steam, a value of $210 \mathrm{~kJ} / \mathrm{mol}$ was estimated and for the case using $\mathrm{CO}_{2}$, the apparent activation energy was $164 \mathrm{~kJ} / \mathrm{mol}$.

In order to evaluate the bauxite waste performance in the combustion of the char gasification products, both using steam and $\mathrm{CO}_{2}$ as gasifying agents, the combustion efficiency defined by equation (24) was represented in Figure 8 versus de oxygen-carrier conversion. According to the results in Figure $8(\mathrm{~A})$, the combustion efficiency was high at all the temperatures tested gasifying with steam. Moreover, in the conversion interval 0-0.3 the efficiency values were similar and higher than 0.97 in all cases. This could be attributed to the high reactivity of bauxite waste to $\mathrm{H}_{2}$, one of the main gases generated in char gasification, at all the temperatures tested. The efficiency decreases as the oxygen-carrier conversion increases, as there is less oxygen available to complete $\mathrm{H}_{2}$ and $\mathrm{CO}$ combustion and therefore these gases escape from the bauxite waste bed as unburnt products. The efficiency values observed in Figure 8 (B) correspond to those obtained in experiments with $\mathrm{CO}_{2}$ at different temperatures. In this case, the combustion efficiency increases with temperature, from values close to 0.8 at $900^{\circ} \mathrm{C}$ to reach values close to 0.9 in the experiment at the highest temperature tested, i.e. 
$980^{\circ} \mathrm{C}$. These results highlight the increase in the bauxite waste reactivity to $\mathrm{CO}$ with temperature, as this gas is the main product in char gasification with $\mathrm{CO}_{2}$ according to equation (3). Similarly to what was observed in the experiments with steam, the value of the combustion efficiency decreases as the amount of oxygen transferred by bauxite waste to the gases decreases. The efficiency values obtained in this work are higher than those previously obtained by our research group in experiments with ilmenite [21]. Working with ilmenite, combustion efficiencies oscillated between $0.89\left(900^{\circ} \mathrm{C}\right)$ and $0.95\left(1000^{\circ} \mathrm{C}\right)$ using steam. The values for char gasification in $\mathrm{CO}_{2}$ were also lower, ranging from 0.59 at $900^{\circ} \mathrm{C}$ to 0.65 at $1000^{\circ} \mathrm{C}$. These results confirm the higher reactivity of bauxite waste in the $i G$-CLC process compared to ilmenite. The higher reactivity will decrease the solids inventory needed to achieve adequate gasification rates and combustion of the gasification products when compared to ilmenite.

\subsubsection{Effect of the gasifying agent}

According to the results showed above in Figures 7 and 8, the use of $\mathrm{CO}_{2}$ as gasifiying agent implies both a significant reduction in the char gasification rate and the combustion efficiency values, as the bauxite waste is not as reactive to $\mathrm{CO}$ as it is to $\mathrm{H}_{2}$. But still, the introduction of certain amount of $\mathrm{CO}_{2}$ in the gasifying stream could be economically beneficial if a steep decrease in the efficiency of the process is avoided. Therefore some experiments were conducted with the diluted bauxite waste bed using different $\mathrm{H}_{2} \mathrm{O}: \mathrm{CO}_{2}$ molar ratios in the gaseous stream, i.e. 50:50, 70:30 and 90:10. The experiments were conducted at two different temperatures, 900 and $980^{\circ} \mathrm{C}$. 
Figure 9 shows the instantaneous rate of char conversion as a function of char conversion using different $\mathrm{H}_{2} \mathrm{O}: \mathrm{CO}_{2}$ molar ratios in the feeding stream at $900^{\circ} \mathrm{C}$ and $980^{\circ} \mathrm{C}$, respectively. As a reference, experiments with only steam or $\mathrm{CO}_{2}$ as gasifying agent have been also included. In both Figures 9 (A) and (B), the rate of char conversion increases as the molar ratio $\mathrm{H}_{2} \mathrm{O}: \mathrm{CO}_{2}$ increases. The values obtained at the highest temperature were around four times the values obtained at $900^{\circ} \mathrm{C}$. Table 4 summarizes the average values for the rate of char conversion determined for the different experiments and compares them with the values obtained in similar experiments at $900^{\circ} \mathrm{C}$ using ilmenite as oxygen carrier $[21,27]$. At $900^{\circ} \mathrm{C}$, the values obtained for the different mixtures were similar for both oxygen carriers, although the amount of oxygen available in the experiments was lower than in the case of ilmenite.

The time values for the char conversion to reach $0.95\left(t_{95}\right)$ were calculated using equation (16) for both temperatures and plotted versus the $\mathrm{H}_{2} \mathrm{O}$ percentage in the gasification feed in Figure 10. The time to almost completely gasify the introduced char decreases with the increase in the percentage of steam fed. The decay is steeper for $900^{\circ} \mathrm{C}$, but at both temperatures tested, the differences between the $t_{95}$ values tend to be small for steam percentages higher than $50 \%$. At the highest temperature tested $\left(980^{\circ} \mathrm{C}\right)$, the $t_{95}$ values for steam percentages higher than 50\% were similar $(12.5,10,8.1$ and $7.1 \mathrm{~min}$ for 50, 70, 90 and $100 \% \mathrm{H}_{2} \mathrm{O}$, respectively). Therefore, regarding the gasification efficiency, it would be possible to operate with $\mathrm{H}_{2} \mathrm{O}: \mathrm{CO}_{2}$ molar ratios close to 50:50. Nevertheless, not only high gasification efficiencies but also high combustion efficiencies of the gasification products are desired in order to optimize the performance of the $i \mathrm{G}$-CLC process. Figure 11 presents the corresponding averaged values for the combustion efficiencies $\left(\eta_{C}\right)$ in the experiments with $\mathrm{H}_{2} \mathrm{O}$ and $\mathrm{CO}_{2}$ mixtures. The averaged combustion efficiency increases as the steam percentage in the feed increases at both temperatures. However, and in order to reach 
combustion efficiencies higher than 0.95 , the amount of $\mathrm{CO}_{2}$ introduced should not exceed $30 \%$, according to the experimental conditions presented in this work.

An experiment was also conducted in order to analyze if the solid-solid reaction between the bauxite waste and char was contributing in some extent to the char conversion. For that purpose, the fluidizing agent used was nitrogen. The bauxite waste was heated up to $900^{\circ} \mathrm{C}$ and a load of $1.5 \mathrm{~g}$ of char was introduced. The product stream was analyzed during $120 \mathrm{~min}$ and no significant amounts of carbonaceous products $\left(\mathrm{CO}, \mathrm{CO}_{2}\right)$ were detected. Therefore it was concluded that the solid-solid contribution to the carbon conversion was negligible in this case, similarly to what was found before by other authors $[21,38,52]$. Char gasification must proceed as an intermediate step in the coal conversion process using bauxite waste as oxygen carrier.

\subsection{Fluidization behaviour and structural changes in bauxite waste particles}

The bauxite waste sample used in this work was subjected to several consecutive redox cycles at high temperature in the batch fluidized-bed previously described. No defluidization or agglomeration problems were detected at any time during the experiments performed. The total operation time was 50 hours. In a previous work, good fluidization properties of this material were observed [35]. Here no influence on the bauxite waste fluidizing properties was observed under the experimental conditions in this work, i.e. when the oxygen carrier particles are in contact with ashes coming from coal.

After this time, the bauxite waste sample was extracted and analyzed in order to determine the possible structural changes undergone by it. The most interesting conclusions can be 
obtained from the SEM images and EDX profiles for $\mathrm{Al}$ and Fe of fresh and used particles shown in Figure 12. No ash particles from the char used were observed stuck to the bauxite waste particles. According to the SEM pictures, some morphological changes were observed in the particles. The bauxite waste has increased its porosity after several cycles using char as fuel. Besides, there is a change in the $\mathrm{Al}$ and Fe distribution throughout the particle. In the calcined sample, the surface seems to be alumina-enriched. After operation in the FB, the EDX analysis revealed a more homogenous distribution of both metals through the particle.

\subsection{Discussion}

The experiments showed in this work were carried out in a batch fluidized-bed reactor. The gasification rates and combustion efficiencies were obtained with two different $\mathrm{O} / \mathrm{C}$ molar ratios. In this section, these results will be used in order to estimate the solids inventory in the fuel reactor of a CLC system that allows complete combustion of the gasification products and a determined value of char conversion in the reactor.

From the reactivity data obtained in this work, an estimation of the solids inventory in the fuel-reactor $\left(m_{F R}\right)$ in an $i G$-CLC system can be done according to the following equation:

$$
m_{F R}=\frac{m_{O}}{r_{O, \text { inst }} \cdot \frac{L H V}{C_{\text {fixed }}}}
$$

where $m_{O}$ is the stoichiometric oxygen $(\mathrm{kg})$ needed per $\mathrm{kg}$ of carbon introduced to the system, $L H V$ corresponds to the low heating value of the coal, $C_{\text {fixed }}$ is the percentage of fixed carbon in the coal and $r_{O, \text { inst }}$ represents the experimental value of the rate of oxygen transfer by the 
oxygen-carrier to the fuel at different reaction conditions $(\mathrm{kg} / \mathrm{s})$ per $\mathrm{kg}$ of oxygen-carrier. The solids inventory $\left(m_{F R}\right)$ represents the amount of solids to burn the gasification products per $\mathrm{MW}_{\text {th }}$ of fuel. The combustion of volatiles from coal is not considered at this point, because the experiments were carried out with char.

For the South African coal used in this work, the value of $m_{O}$ can be estimated as $2.69 \mathrm{~kg}$ oxygen $/ \mathrm{kg}$ carbon. The low heating value of the South African coal was $25500 \mathrm{~kJ} / \mathrm{kg}$. The highest value for $r_{O, \text { inst }}$ was obtained at the highest temperature tested $\left(980^{\circ} \mathrm{C}\right)$ and using steam as gasifiying agent. Two different values have been obtained in this work, one corresponding to the non-diluted bauxite waste experiments $\left(3.4 \cdot 10^{-5} \mathrm{~kg} \mathrm{O} / \mathrm{s} \cdot \mathrm{kg} \mathrm{OC}\right)$. Considering the previous values, the solids inventory in the fuel-reactor needed would be $1726 \mathrm{~kg} / \mathrm{MW}_{\text {th. }}$ In this case, complete conversion of the gasification products to $\mathrm{CO}_{2}$ and $\mathrm{H}_{2} \mathrm{O}$ was achieved which corresponds to $100 \%$ combustion efficiency. In the conditions where not complete combustion of $\mathrm{CO}$ and $\mathrm{H}_{2}$ where obtained, i.e. diluting the bauxite waste bed with alumina 50:50 (wt\%), the $r_{O \text {,inst }}$ value resulted $7.3 \cdot 10^{-5} \mathrm{~kg} \mathrm{O} / \mathrm{s} \cdot \mathrm{kg}$ OC, which would correspond to a solids inventory of $812 \mathrm{~kg} / \mathrm{MW}_{\text {th }}$. In this case, the combustion efficiency observed in Figure 8 was 99\%.

Additional information about the char conversion in the $i$ G-CLC system can be obtained from the reactivity data in this work, as has been previously done with ilmenite [21]. In a system including a carbon separation unit, the mass balance for carbon in char was done. An estimation for the char conversion, $X_{C}$, defined as the fraction of carbon introduced with the char fed that exits as gaseous product from the fuel-reactor, was obtained as: 


$$
X_{C}=1-\frac{F_{O C} \cdot\left(1-\eta_{C S}\right)}{r_{C, \text { inst }} \cdot m_{F R}+F_{O C} \cdot\left(1-\eta_{C S}\right)}
$$

where $r_{C \text {,inst }}$ is the char gasification rate obtained experimentally, $F_{O C}$, is the circulation flow rate of the bauxite waste in an $i G$-CLC system, $m_{F R}$ is the bauxite waste inventory in the fuelreactor and $\eta_{C S}$ the efficiency of the carbon separation system.

The values of $r_{C, \text { inst }}$ obtained in this work were presented in Tables 3 and 4 . For the calcuations, $1 \mathrm{MW}_{\text {th }}$ was taken as reference and steam as gasifying agent. Considering the oxygen transfer capacity of the bauxite waste $\left(R_{O C}=2.4 \%\right)$, the stoichiometric circulation flow rate of to fully convert coal to $\mathrm{CO}_{2}$ and $\mathrm{H}_{2} \mathrm{O}$ was $3.5 \mathrm{~kg} / \mathrm{s}$, i.e. with an oxygen-carrier to fuel ratio $\phi=1$. However, the optimum oxygen-carrier to fuel ratio when using solid fuels should be in the range 1.1-1.2, according to Cuadrat et al. [53]. Therefore, a $\phi$ value of 1.2 was chosen. Figure 13 shows the values for the char conversion $\left(X_{c}\right)$ obtained for different values of efficiency in the carbon separation system considering both of the solids inventories previously calculated with equation (26) from experiments without or with dilution. Obviously, the char conversion increases as the efficiency of the carbon separation system also increases. Assuming 0.9 as an adequate efficiency value for the carbon separation system, the values of the char conversion are higher than 0.9 in both cases. These results allow to calculate an estimation of the carbon capture efficiency in an $i G$-CLC process where a carbon separation unit is incorporated and $1 \mathrm{MW}_{\text {th }}$ South African coal is fed, assuming that all the carbon in the coal volatiles is captured. The carbon capture efficiency $\left(\eta_{C C}\right)$ indicates the fraction of the carbon introduced converted to gas in the fuel-reactor and it is calculated as: 
$\eta_{C C}=1-\frac{C_{\text {fixed }}}{C_{\text {coal }}} \cdot\left(1-X_{C}\right)$

where $C_{\text {coal }}$ is the percentage of carbon in the coal.

The carbon capture efficiency values were calculated and plotted in Figure 13 for the two solids inventories considered. The carbon capture efficiency is 0.98 using $1726 \mathrm{~kg}$ bauxite waste $/ \mathrm{MW}_{\text {th }}$ and 0.95 using $812 \mathrm{~kg} / \mathrm{MW}_{\text {th }}$ considering 0.9 the efficiency value for the carbon separation system. It is interesting to note that these values correspond to partially activated bauxite waste. Depending on the further post-treatment of the flue gases from the fuel-reactor and the requirements for a safe storage of the $\mathrm{CO}_{2}$-concentrated stream generated, the lowest solids inventory could be adequate for operation, what would decrease the dimensions of the fuel-reactor needed. According to these results, it can be concluded that the bauxite waste is a promising material among the different Fe-based oxygen carriers presented in literature in order to be used with solid fuels.

\section{Conclusions}

A bauxite waste has been evaluated as a potential oxygen carrier for the $i G$-CLC of coal process. Experiments were performed using char from a bituminous coal as fuel and different operating variables were studied, such as temperature and the composition of the gasifying mixture. Both char gasification and combustion of the gasification products were analyzed.

Bauxite waste reactivity increased after several cycles using char as fuel. In the same conditions, the bauxite waste displayed higher reactivity to the gasification products than ilmenite. Thus, higher combustion efficiencies were reached using steam or $\mathrm{CO}_{2}$ as gasifying 
agents than with ilmenite. The higher reactivity will decrease the solids inventory needed to achieve adequate gasification rates and combustion of the gasification products when compared to ilmenite.

In experiments with different amounts of bauxite waste in the fluidized-bed, it was observed that the incomplete combustion of the gasification products reduced the char gasification velocity.

Experiments were performed with different $\mathrm{H}_{2} \mathrm{O}: \mathrm{CO}_{2}$ ratios. Both the char gasification rate and the combustion efficiency increased as the percentage of steam in the feeding increased. A molar ratio 70:30 turned out to be adequate to reach combustion efficiencies higher than 0.95 at the different temperatures tested $\left(900\right.$ and $\left.980^{\circ} \mathrm{C}\right)$. Regardless the gasifying agent used, char gasification rate and combustion efficiency were notably increased with temperature, although the extent of this increase was larger using steam.

A theoretical approximation of the solids inventory needed in an $i \mathrm{G}-\mathrm{CLC}$ system was carried out by using experimental results. Combustion efficiencies of 0.99 were estimated for 812 $\mathrm{kg} / \mathrm{MW}_{\text {th }}$, whereas a carbon capture efficiency of 0.95 could be reached when the efficiency of the carbon separation system is 0.9 .

\section{Acknowledgments}

The authors thank the Spanish Ministry for Science and Innovation for the financial support via the ENE2010-19550 project. T. Mendiara thanks for the "Juan de la Cierva" post-doctoral contract awarded by this Ministry. The authors also thank to Alcoa Europe-Alúmina 
Española S.A. for providing the solid material used in this work. G. Ferrer is acknowledged for his contribution to the experimental results. 


\section{Bibliography}

[1] IEA World Energy Outlook 2010. Paris, France: OECD/IEA; 2010.

[2] MIT Study on the future of coal. ISBN 978-0-615-14092; 2007.

[3] A.F. Ghoniem, Needs, resources and climate change: clean and efficient conversion technologies, Prog. Energy Combust. Sci. 37 (2011) 15-51.

[4] Carbon Capture and Storage. IPCC Report. New York: Cambridge University Press; 2005.

[5] L.I. Eide, M. Anheden, A. Lyngfelt, C. Abanades, M. Younes, D. Clodic et al., Novel capture processes, Oil \& Gas Sci. Technol. 60 (2005) 497-508.

[6] H.J. Ryu, G.T. Jin, C.K. Yi, Demonstration of inherent $\mathrm{CO}_{2}$ separation and no $\mathrm{NO}_{\mathrm{x}}$ emission in a $50 \mathrm{~kW}$ chemical-looping combustor: Continuous reduction and oxidation experiment, in: M. Wilson, T. Morris, J. Gale, K. Thambibutu (Eds.), Proceedings of the Seventh International Conference of Greenhouse Gas Control Technologies, Elsevier Ltd., Amsterdam (The Netherlands), 2005, pp. 1907.

[7] A. Abad, T. Mattisson, A. Lyngfelt, M. Rydén, Chemical-looping combustion in a $300 \mathrm{~W}$ continuously operating reactor system using a manganese-based oxygen carrier. Fuel 85 (2006) 1174-1185.

[8] A. Lyngfelt, H. Thunman, Construction and $100 \mathrm{~h}$ of operational experience of a $10-\mathrm{kW}$ chemical-looping combustor, in: D. Thomas, S. Benson (Eds.), Carbon Dioxide Capture for 
Storage in Deep Geologic Formations-Results from the $\mathrm{CO}_{2}$ Capture Project, Elsevier Science, Amsterdam (The Netherlands), 2005, Chapter 36.

[9] C. Linderholm, A. Abad, T. Mattisson, A. Lyngfelt, $160 \mathrm{~h}$ of chemical-looping combustion in a $10 \mathrm{~kW}$ reactor system with a NiO-based oxygen carrier, Int. J. Greenhouse Gas Control 2 (2008) 520-530.

[10] C. Linderholm, T. Mattisson, A. Lyngfelt, Long-term integrity testing of spray-dried particles in a 10-kW chemical-looping combustor using natural gas as fuel, Fuel 88 (2009) 2083-2096.

[11] P. Kolbitsch, T. Pröll, J. Bolhar-Nordenkampf, H. Hofbauer, Operating experience with chemical looping combustion in a $120 \mathrm{~kW}$ dual circulating fluidized bed (DCFB) unit, Int. J. Greenhouse Gas Control 4 (2010) 180-185.

[12] J. Adánez, P. Gayán, J. Celaya, L.F. de Diego, F. García-Labiano, A. Abad, Chemical looping combustion in a $10 \mathrm{~kW}$ th prototype using a $\mathrm{CuO} / \mathrm{Al}_{2} \mathrm{O}_{3}$ oxygen carrier: effect of operating conditions on methane combustion, Ind. Eng. Chem. Res. 45 (2006) 6075-6080.

[13] J. Adánez, A. Abad, F. García-Labiano, P. Gayán, L.F. de Diego, Progress in chemicallooping combustion and reforming technologies, Prog. Energ. Combust. 38 (2012) 215-282.

[14] H. Jin, M. Ishida, A new type of coal gas fueled chemical-looping combustion, Fuel 83 (2004) 2411-2417. 
[15] L-S. Fan, F. Li, Chemical looping technology and its fossil energy conversion applications, Ind. Eng. Chem. Res. 49 (2010) 10200-10211.

[16] Y. Cao, W-P. Pan, Investigation of chemical looping combustion by solid fuels. 1. Process analysis, Energy Fuels 20 (2006) 1836-1844.

[17] T. Mattisson, A. Lyngfelt, H. Leion, Chemical-looping with oxygen uncoupling for combustion of solid fuels, Int. J. Greenhouse Gas Control 3 (2009) 11-19.

[18] J.S. Dennis, S.A. Scott, In situ gasification of a lignite coal and $\mathrm{CO}_{2}$ separation using chemical looping with a Cu-based oxygen carrier, Fuel 89 (2010) 1623-1640.

[19] H. Leion, T. Mattissson, A. Lyngfelt, Use of ores and industrial products as oxygen carriers in chemical-looping combustion, Energy Fuels 23 (2009) 2307-2315.

[20] J. Adánez, A. Cuadrat, A. Abad, P. Gayán, L.F. de Diego, F. García-Labiano, Ilmenite activation during consecutive redox cycles in chemical-looping combustion, Energy Fuels 24 (2010) 1402-1413.

[21] A. Cuadrat, A. Abad, J. Adánez, L.F. de Diego. F. García-Labiano, P. Gayán, Prompt considerations on the design of chemical-looping combustion of coal from experimental tests Fuel (2012) doi: 10.1016/j.fuel.2012.01.050

[22] N. Berguerand, A. Lyngfelt, Design and operation of a $10 \mathrm{kWth}$ chemical-looping for solid fuels - Testing with South African coal, Fuel 87 (2008) 2713-2726. 
[23] N. Berguerand, A. Lyngfelt, The use of petroleum coke as fuel in a $10 \mathrm{~kW}_{\text {th }}$ chemicallooping combustor, Int. J. Greenhouse Gas Control 2 (2008) 169-179.

[24] A. Cuadrat, A. Abad, F. García-Labiano, P. Gayán, L.F. de Diego, J. Adánez, The use of ilmenite as oxygen-carrier in a $500 \mathrm{~W}_{\text {th }}$ chemical-looping coal combustion unit, Int. J. Greenhouse Gas Control 5 (2011) 1630-1642.

[25] N. Berguerand, A. Lyngfelt, Chemical-looping combustion of petroleum coke using ilmenite in a $10 \mathrm{~kW}_{\text {th }}$ unit - High temperature operation, Energy Fuels 23 (2009) 5257-5268.

[26] H. Leion, E. Jerndal, B-M, Steenari, S. Hermansson, M. Israelsson, E. Jansson, M. Johnsson, R. Thunberg, A. Vadenbo, T. Mattisson, A. Lyngfelt, Solid fuels in chemicallooping combustion using oxide scale and unprocessed iron ore as oxygen carriers, Fuel 88 (2009) 1945-1954.

[27] H. Leion, T. Mattisson, A. Lyngfelt, Solid fuels in chemical-looping combustion, Int. J. Greenhouse Gas Control 2 (2008) 180-193.

[28] H. Leion, T. Mattisson, A. Lyngfelt, Chemical looping combustion of solid fuels in a laboratory fluidized-bed reactor, Oil \& Gas Sci. Technol. 66 (2011) 201-208.

[29] N. Berguerand, A. Lyngfelt, Batch testing of solid fuels with ilmenite in a $10 \mathrm{~kW}_{\text {th }}$ chemical-looping combustor, Fuel 89 (2010) 1749-1762. 
[30] N. Berguerand, A. Lyngfelt, T. Mattisson, P. Markström, Chemical looping combustion of solid fuels in a $10 \mathrm{~kW}_{\text {th }}$ unit, Oil \& Gas Sci Technol 66 (2011) 181-191.

[31] N. Berguerand, A. Lyngfelt, Operation in a $10 \mathrm{~kW}_{\text {th }}$ chemical-looping combustor for solid fuel - Testing with a Mexican petroleum coke, Energy Procedia 1 (2009) 407-414.

[32] E. Jerndal, H. Leion, L. Axelsson, T. Ekvall, M. Hedberg, K. Johansson, M. Källén, R. Svensson, T. Mattisson, A. Lyngfelt, Using low-cost iron-based materials as oxygen carriers for chemical looping combustion, Oil \& Gas Sci. Technol. 66 (2011) 235-248.

[33] A. Fossdal, E. Bakken, B.A. Øye, C. Schøning, I. Kaus, T. Mokkelbost, Y. Larring, Study of inexpensive oxygen carriers for chemical looping combustion, Int. J. Greenhouse Gas Control 5 (2011) 483-488.

[34] T. Mattisson, A. Lyngfelt, P. Cho, The use of iron oxide as an oxygen carrier in chemical-looping combustion of methane with inherent separation of $\mathrm{CO}_{2}$, Fuel 80 (2001) 1953-1962.

[35] T. Mendiara, A. Abad, L.F. de Diego, F. García-Labiano, P. Gayán, J. Adánez, Use of a Fe-based residue from alumina production as oxygen carrier in chemical looping combustion, Energy Fuels 26 (2012) 1420-1431.

[36] A. Cuadrat, A. Abad, J. Adánez, L.F. de Diego, F. Garcia-Labiano, P. Gayán, Behavior of ilmenite as oxygen carrier in chemical-looping combustion, Fuel Process. Technol. 94 (2012) 101-112. 
[37] Z. Gao, L. Shen, J. Xiao, M. Zheng, J. Wu, Analysis of reactivity of Fe-based oxygen carrier with coal during chemical-looping combustion, J. Fuel Chem. Technol. 37 (2009) $513-520$.

[38] H. Leion, T. Mattisson, A. Lyngfelt, The use of petroleum coke as fuel in chemical looping combustion, Fuel 86 (2007) 1947-1958.

[39] J. Wu, L. Shen, J. Hao, H. Gu, Chemical looping combustion of coal in a $1 \mathrm{~kW}_{\text {th }}$ reactor with iron ore as an oxygen carrier, Proceedings $1^{\text {st }}$ International Conference on ChemicalLooping, Lyon, France, 2010.

[40] T. Mendiara, A. Abad, L.F. de Diego, F. García-Labiano, P. Gayán, J. Adánez, Use of red mud as oxygen carrier in chemical looping combustion of coal, $3^{\text {rd }}$ High Temperature Solid Looping Network Meeting, Vienna, Austria; 2011.

[41] R.K. Paramguru, P.C. Rath, V.N. Misra, Trends in red mud utilization, Miner Process Extr M 26 (2005) 1-29.

[42] D.J. Cooling, D.J. Glenister, Practical aspects of dry residue disposal. Light Met. 1992 (1991) 25-31.

[43] A.R. Hind, S.K. Bhargava, S.C. Grocott, The surface chemistry of Bayer process solids: a review, Colloid Surface A 146 (1999) 359-374. 
[44] M. Ortiz, P. Gayán, L.F. de Diego, F. García-Labiano, A. Abad, M.A. Pans, J. Adánez, Hydrogen production with $\mathrm{CO} 2$ capture by coupling steam reforming of methane and chemical-looping combustion: use of an iron-based waste product as oxygen carrier burning a PSA tail gas, J. Power Sources 196 (2011) 4370-4381.

[45] A. Abad, F. García-Labiano, L.F. de Diego, P. Gayán, J. Adánez, Reduction kinetics of $\mathrm{Cu}-$, Ni- and Fe-based oxygen carriers using syngas $\left(\mathrm{CO}+\mathrm{H}_{2}\right)$ for chemical looping combustion, Energy Fuels 21 (2007) 1843-1853.

[46] M. Johansson, T. Mattisson, A. Lyngfelt, Comparison of oxygen carriers for chemicallooping combustion, Therm. Sci. 10 (2006) 93-107.

[47] P. Cho, T. Mattisson, A. Lyngfelt, Comparison of iron-, nickel, copper- and manganesebased oxygen carriers for chemical-looping combustion, Fuel 83 (2004) 1215-1225.

[48] J. Adánez, L.F. de Diego, F. García-Labiano, P. Gayán, A. Abad, J.M. Palacios, Selection of oxygen carriers for chemical-looping combustion, Energy Fuels 18 (2004) 371377.

[49] H. Leion, A. Lyngfelt, M. Johansson, E. Jerndal, T. Mattisson, The use of ilmenite as an oxygen carrier in chemical-looping combustion, Chemical Engineering Research and Design 86 (2008) 1017-1026. 
[50] M. Rydén, E. Cleverstam, A. Lyngfelt, T. Mattisson, Waste products from the steel industry with $\mathrm{NiO}$ as additive as oxygen carrier for chemical-looping combustion, Int. J. Greenhouse Gas Control 3(2009) 693-703.

[51] Johnson JL. Fundamentals of Coal Gasification. Chapter 23. In: Chemistry of Coal Utilization. Ed. Elliot MA. Wiley \& Sons. 1981. New York.

[52] T.A. Brown, J.S. Dennis, S.A. Scott, J.F. Davidson, A.N. Hayhurst, Gasification and chemical-looping combustion of a lignite char in a fluidized bed of iron ore, Energy Fuels 24 (2010) 3034-3048.

[53] A. Cuadrat, A. Abad, F. García-Labiano, P. Gayán, L.F. de Diego, J. Adánez, Effect of operating conditions in chemical-looping combustion of coal in a $500 \mathrm{~W}_{\text {th }}$ unit, Int. J. Greenhouse Gas Control 6 (2012) 153-163. 


\section{Tables}

Table 1. Characterization of calcined bauxite waste sample

\begin{tabular}{ll}
\hline $\mathrm{Fe}_{2} \mathrm{O}_{3}(\% \mathrm{wt})$ & $71^{\mathrm{a}}$ \\
XRD main phases & $\mathrm{Fe}_{2} \mathrm{O}_{3}, \beta-\mathrm{Al}_{2} \mathrm{O}_{3}$ \\
Crushing strength (N) & 2.8 \\
Oxygen transport capacity, $R_{O C},(\%)$ & 2.4 \\
Porosity (\%) & 3.7 \\
Skeletal density $\left(\mathrm{kg} / \mathrm{m}^{3}\right)$ & 4500 \\
Specific surface area, BET $\left(\mathrm{m}^{2} / \mathrm{g}\right)$ & 0.1 \\
\hline${ }^{\mathrm{a}}$ Determined by TGA
\end{tabular}


Table 2. Proximate and ultimate analyses of coal and char from bituminous South African coal $(\%$ weight $)$

Proximate analysis

\begin{tabular}{lcc}
\hline & Coal & Char \\
\hline Moisture & 4.2 & 0.9 \\
Ash & 14.3 & 20.0 \\
Volatile matter & 25.5 & 1.1 \\
Fixed carbon & 56.0 & 78.0 \\
\hline Ultimate analysis & & \\
\hline & Coal & Char \\
\hline Carbon & 69.3 & 76.5 \\
Hydrogen & 4.0 & 0.2 \\
Nitrogen & 2.0 & 1.6 \\
Sulfur & 1.0 & 0.8 \\
Oxygen & 5.2 & 0 \\
\hline Determined & & \\
\hline
\end{tabular}

${ }^{\mathrm{b}}$ Determined by difference 
Table 3. Average values of the instantaneous rate of char conversion, $r_{C, \text { inst }}(t)$ and residence time to convert $95 \%$ of char, $t_{95}$, at different temperatures for $\mathrm{H}_{2} \mathrm{O}$ or $\mathrm{CO}_{2}$ as gasification agents using ilmenite (ILM) or bauxite waste (BW) as oxygen carriers (OC). I: Inventory.

\begin{tabular}{|c|c|c|c|c|c|c|c|c|c|c|c|c|c|c|c|c|c|c|}
\hline & & & \multirow{2}{*}{\multicolumn{8}{|c|}{$r_{C, \text { inst }}(\% / \mathrm{min})$}} & \multirow{2}{*}{\multicolumn{8}{|c|}{$\mathrm{t}_{95}(\mathrm{~min})$}} \\
\hline & & & & & & & & & & & & & & & & & & \\
\hline & & & \multicolumn{4}{|c|}{$\mathrm{H}_{2} \mathrm{O}$} & \multicolumn{4}{|c|}{$\mathrm{CO}_{2}$} & \multicolumn{4}{|c|}{$\mathrm{H}_{2} \mathrm{O}$} & \multicolumn{4}{|c|}{$\mathrm{CO}_{2}$} \\
\hline & & & \multicolumn{4}{|c|}{$\mathrm{T}\left({ }^{\circ} \mathrm{C}\right)$} & \multicolumn{4}{|c|}{$\mathrm{T}\left({ }^{\circ} \mathrm{C}\right)$} & \multicolumn{4}{|c|}{$\mathrm{T}\left({ }^{\circ} \mathrm{C}\right)$} & \multicolumn{4}{|c|}{$\mathrm{T}\left({ }^{\circ} \mathrm{C}\right)$} \\
\hline $\mathrm{OC}$ & $\mathrm{I}(\mathrm{g})$ & $\mathrm{O} / \mathrm{C}$ (molar) & 900 & 950 & 980 & 1000 & 900 & 950 & 980 & 1000 & 900 & 950 & 980 & 1000 & 900 & 950 & 980 & 1000 \\
\hline ILM & 400 & 10.5 & 10.9 & 24.0 & - & 37.3 & 3.4 & 5.2 & - & 6.9 & 27.5 & 12.5 & - & 7.8 & 88.1 & 57.6 & - & 43.4 \\
\hline \multirow[t]{2}{*}{ BW } & 400 & 6.2 & 14.4 & 29.1 & 41.5 & - & - & - & - & - & 20.8 & 10.3 & 7.7 & - & - & - & - & - \\
\hline & 200 & 3.1 & 10.4 & 27.4 & 41.9 & - & 2.1 & 3.4 & 6.6 & - & 28.8 & 10.9 & 7.1 & - & 142.7 & 88.1 & 45.4 & - \\
\hline
\end{tabular}


Table 4. Average values of the instantaneous rate of char conversion, $r_{C, \text { inst }}(t)$, at different temperatures and $\mathrm{H}_{2} \mathrm{O}: \mathrm{CO}_{2}$ molar ratios in the gasifying stream using ilmenite (ILM) or bauxite waste (BW) as oxygen carriers (OC). I: Inventory.

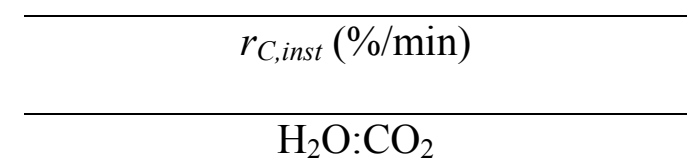

\begin{tabular}{lllllllll}
\hline $\mathrm{T}\left({ }^{\circ} \mathrm{C}\right)$ & OC & I (g) & O/C (molar) & $100: 0$ & $90: 10$ & $70: 30$ & $50: 50$ & $0: 100$ \\
\hline 900 & ILM & 400 & 10.5 & 10.9 & 8.1 & 5.7 & 4.8 & 3.4 \\
& & & & & & & & \\
& BW & 200 & 3.1 & 10.4 & 8.0 & 7.0 & 6.0 & 2.1 \\
\hline 980 & BW & 200 & 3.1 & 41.9 & 37.1 & 30.0 & 23.9 & 6.6 \\
\hline
\end{tabular}




\section{List of Figure Captions}

Figure 1. In situ Gasification Chemical Looping Combustion process.

( $\boldsymbol{-}$ - - ) Optional streams to replace $\mathrm{H}_{2} \mathrm{O}(\mathrm{v})$ by $\mathrm{CO}_{2}$ in the fluidizing gas of fuel reactor and/or the carbon separation system

Figure 2. . Experimental setup: batch fluidized-bed reactor

Figure 3. Gas product distribution (wet basis) and solid conversion evolution in a typical experiment with char as fuel (cycle $15^{\text {th }}$ ). Gasifying agent: $\mathrm{H}_{2} \mathrm{O}$; Char load: $1 \mathrm{~g}$; Bauxite waste in bed: $400 \mathrm{~g} . \mathrm{T}=900^{\circ} \mathrm{C}$. R: reduction and O: Oxidation

Figure 4. Conversion of (A) reduction $\left(X_{r}\right)$ and (B) oxidation $\left(X_{o}\right)$ with time of bauxite waste samples extracted after the $1^{\text {st }}, 4^{\text {th }}, 8^{\text {th }}, 15^{\text {th }}$ and $23^{\text {rd }}$ cycle in the batch fluidized-bed reactor using char as fuel (solid lines). The dashed lines correspond to the curves for calcined and activated bauxite waste obtained in a multicycle test in TGA. Experimental conditions for TGA experiments: $\mathrm{T}=950^{\circ} \mathrm{C}$. (A) $5 \% \mathrm{H}_{2}+40 \% \mathrm{H}_{2} \mathrm{O}$ (B) Air

Figure 5. (A) $\mathrm{CO}$ and $\mathrm{H}_{2}$ molar flow evolution with char conversion and (B) char conversion evolution with time for the experiments performed with bauxite waste (solid line) and sand (dashed line) as bed materials. Bauxite waste in bed: $400 \mathrm{~g} . \mathrm{T}=900^{\circ} \mathrm{C}$; Gasification agent: steam

Figure 6. Instantaneous rate of char conversion, $r_{C, \text { inst }}(t)$, as a function of the char conversion at 900,950 and $980^{\circ} \mathrm{C}$ using steam as gasifying agent. Bauxite waste in bed: $400 \mathrm{~g}$.

Figure 7. Instantaneous rate of char conversion, $r_{C, \text { inst }}(t)$, as a function of the char conversion at 900,950 and $980^{\circ} \mathrm{C}$ using (A) steam and (B) $\mathrm{CO}_{2}$ as fluidizing agents. Bauxite waste in bed: $200 \mathrm{~g}$.

Figure 8. Combustion efficiency, $\eta_{C}$, as a function of the bauxite waste conversion at 900 , 950 and $980^{\circ} \mathrm{C}$ using (A) steam and (B) $\mathrm{CO}_{2}$ as fluidizing agent. Bauxite waste in bed: $200 \mathrm{~g}$. 
Figure 9. Instantaneous rate of char conversion, $r_{C, \text { inst }}(t)$, as a function of the char conversion using different $\mathrm{H}_{2} \mathrm{O}: \mathrm{CO}_{2}$ molar ratios in the gasifying stream at (A) 900 (B) $980^{\circ} \mathrm{C}$. Bauxite waste in bed: $200 \mathrm{~g}$.

Figure 10. Average values of the residence time to convert $95 \%$ of char, $\left(t_{95}\right)$ using different $\mathrm{H}_{2} \mathrm{O}: \mathrm{CO}_{2}$ molar ratios in the gasifying stream at 900 and $980^{\circ} \mathrm{C}$. Bauxite waste in bed: $200 \mathrm{~g}$. Figure 11. Average values of combustion efficiency using different $\mathrm{H}_{2} \mathrm{O}: \mathrm{CO}_{2}$ molar ratios in the gasifying stream at 900 and $980^{\circ} \mathrm{C}$. Bauxite waste in bed: $200 \mathrm{~g}$.

Figure 12. SEM images and EDX profile lines for $\mathrm{Al}$ and $\mathrm{Fe}$ of (A) calcined and (B) used particles after 50 hours of operation in FB with coal char feeding

Figure 13. Char conversion by gasification, $X_{c}$ (squares) and carbon capture efficiency, $\eta_{C C}$ (triangles) in the fuel-reactor as a function of the efficiency of the carbon separation system. In all cases, steam was used as gasifying agent at $980^{\circ} \mathrm{C}$. 


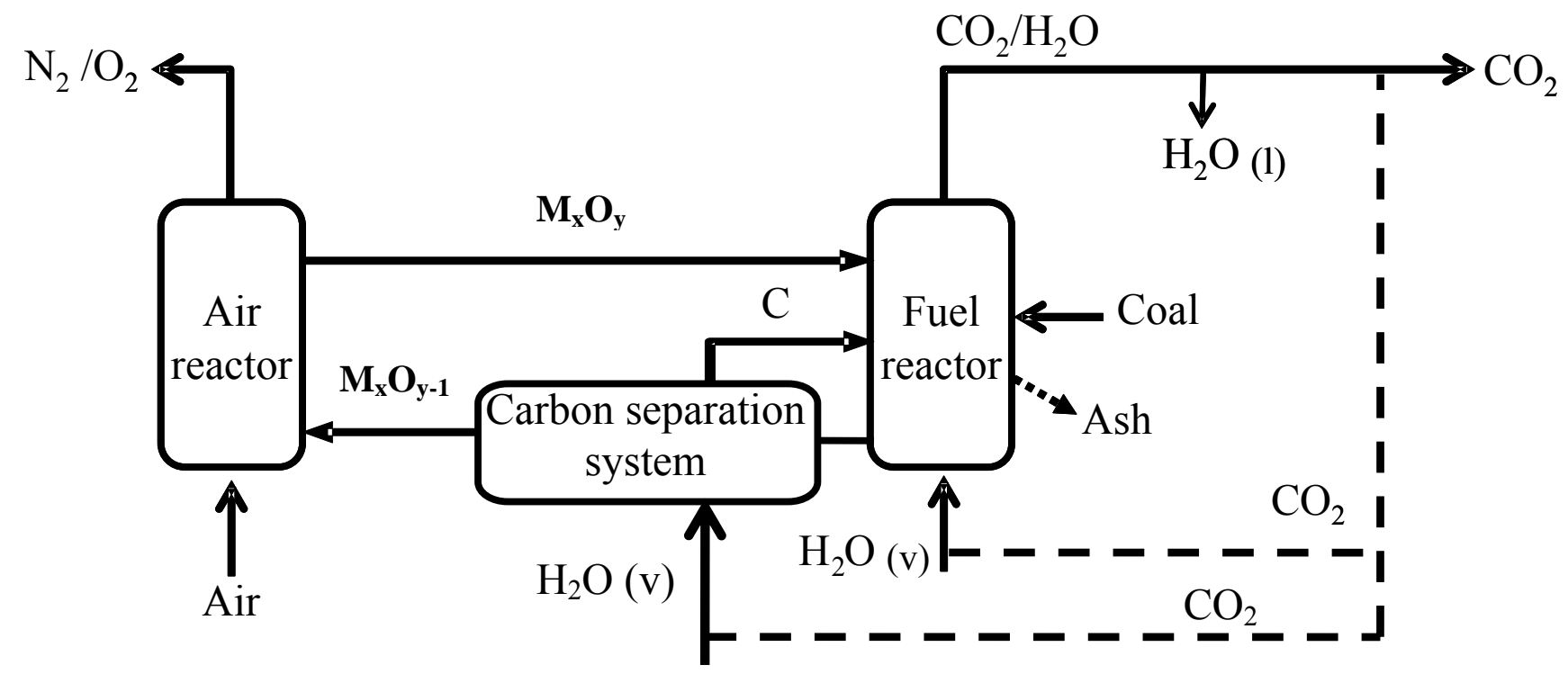

Figure 1. In situ Gasification Chemical Looping Combustion process.

( reactor and/or the carbon separation system 


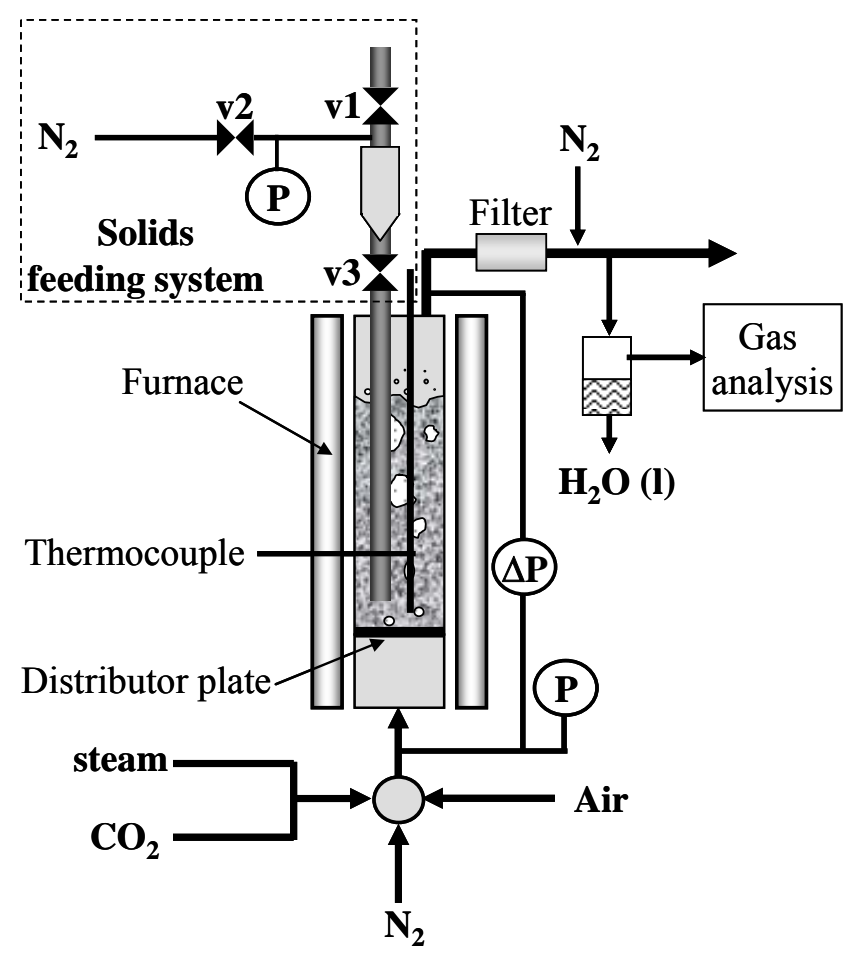

Figure 2. . Experimental setup: batch fluidized-bed reactor 


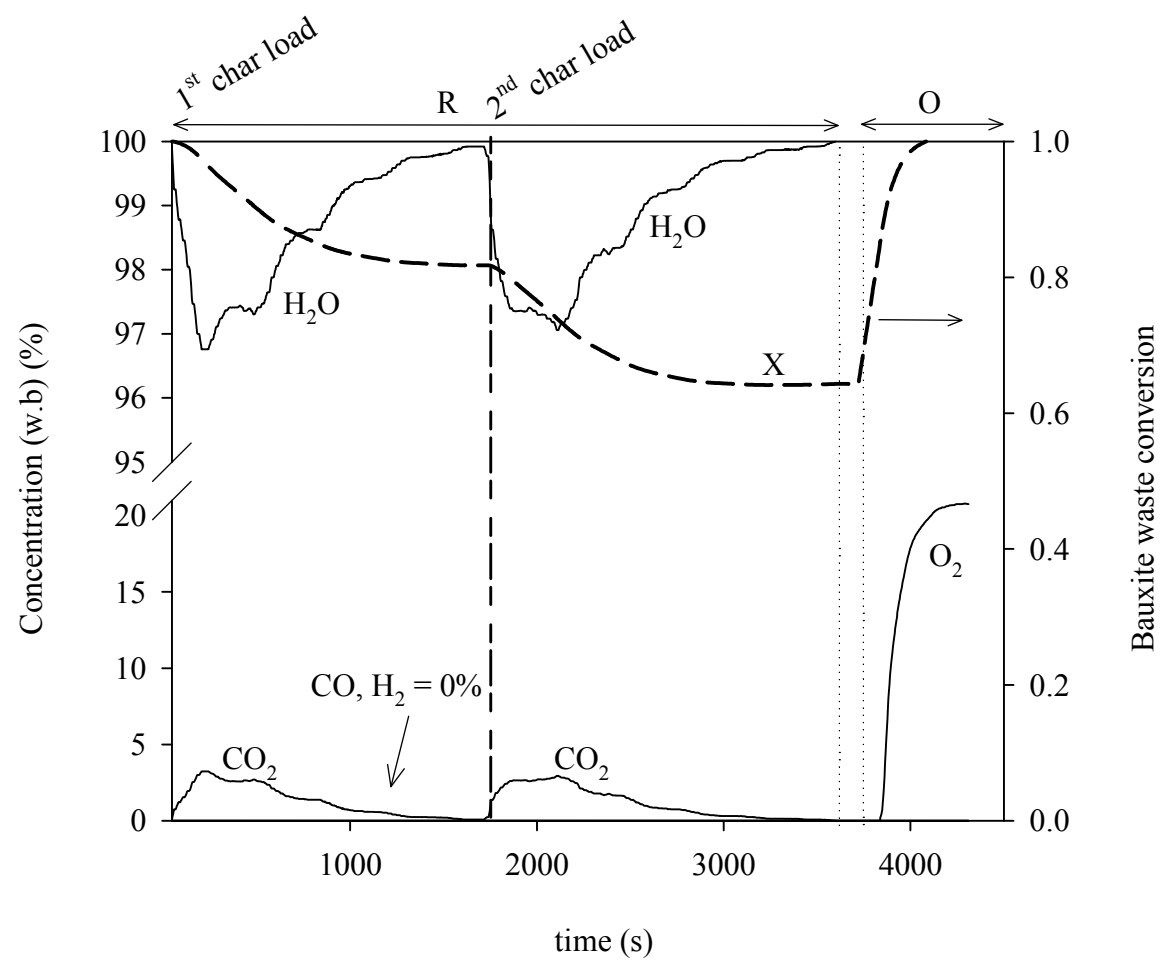

Figure 3. Gas product distribution (wet basis) and solid conversion evolution in a typical experiment with char as fuel (cycle $15^{\text {th }}$ ). Gasifying agent: $\mathrm{H}_{2} \mathrm{O}$; Char load: $1 \mathrm{~g}$; Bauxite waste in bed: $400 \mathrm{~g} . \mathrm{T}=900^{\circ} \mathrm{C}$. R: reduction and O: Oxidation 

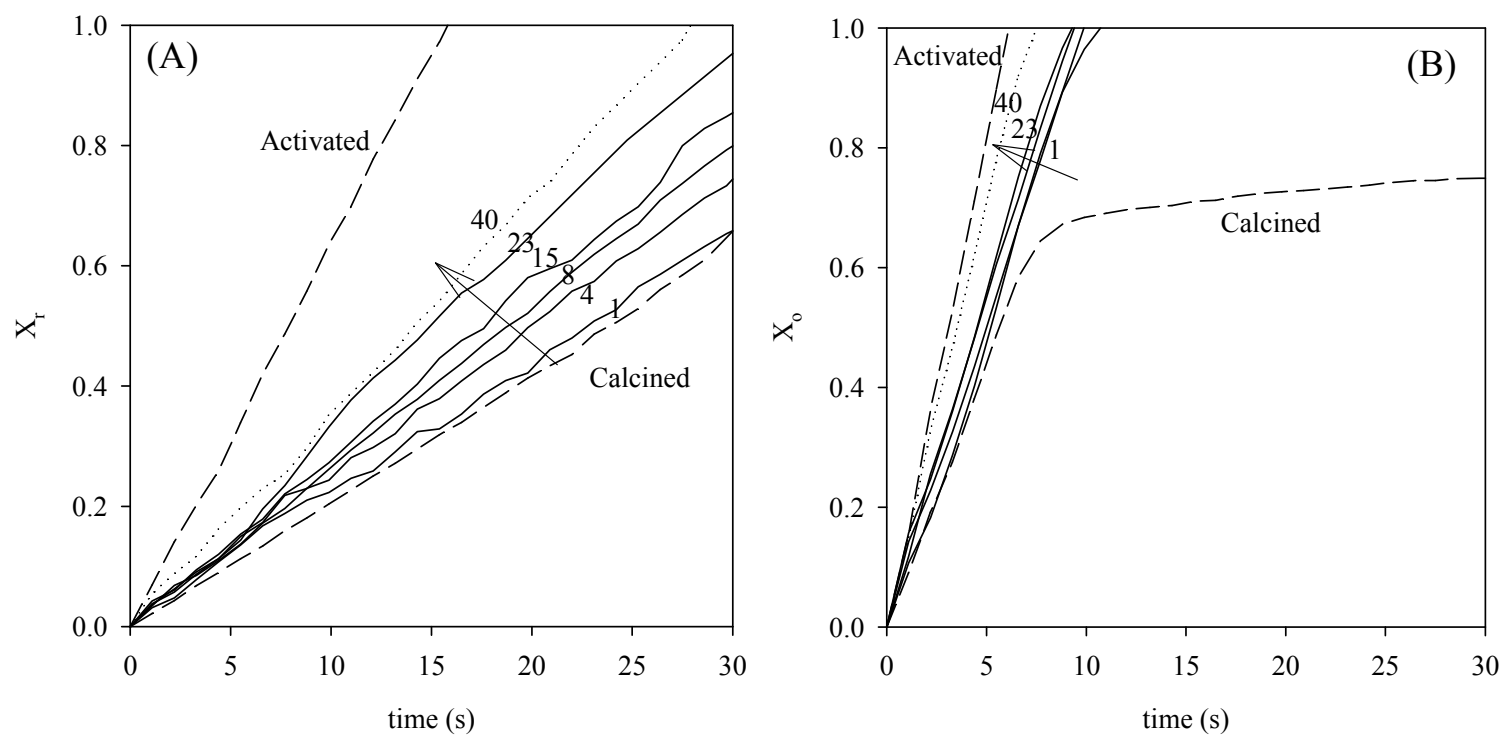

Figure 4. Conversion of $(\mathrm{A})$ reduction $\left(X_{r}\right)$ and (B) oxidation $\left(X_{o}\right)$ with time of bauxite waste samples extracted after the $1^{\text {st }}, 4^{\text {th }}, 8^{\text {th }}, 15^{\text {th }}$ and $23^{\text {rd }}$ cycle in the batch fluidized-bed reactor using char as fuel (solid lines) and at the end of the experiments, $40^{\text {th }}$ cycle (dotted line). The dashed lines correspond to the curves for calcined and activated bauxite waste obtained in a multicycle test in TGA. Experimental conditions for TGA experiments: $\mathrm{T}=950^{\circ} \mathrm{C}$. (A) $5 \%$ $\mathrm{H}_{2}+40 \% \mathrm{H}_{2} \mathrm{O}(\mathrm{B})$ Air 

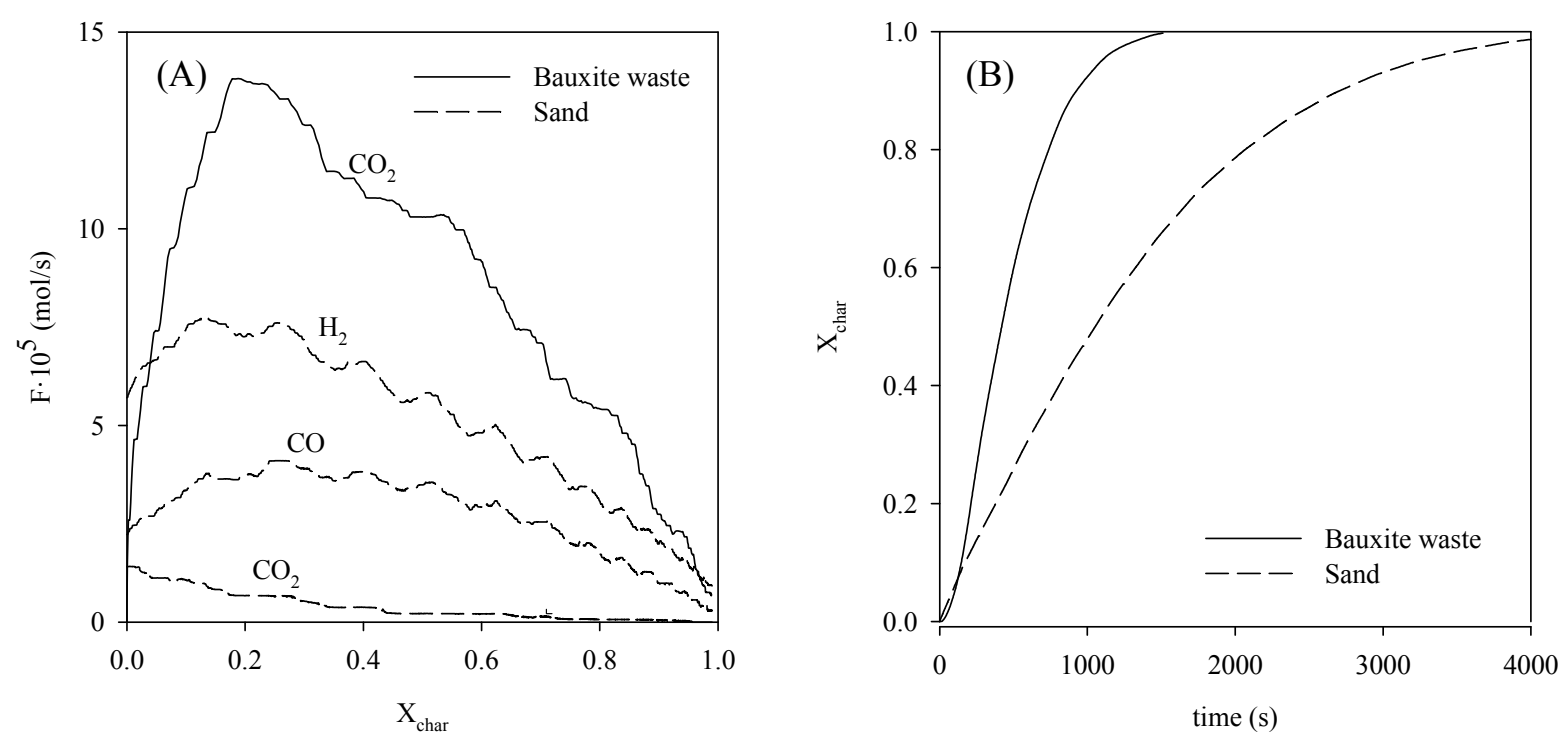

Figure 5. (A) $\mathrm{CO}$ and $\mathrm{H}_{2}$ molar flow evolution with char conversion and (B) char conversion evolution with time for the experiments performed with bauxite waste (solid line) and sand (dashed line) as bed materials. Bauxite waste in bed: $400 \mathrm{~g} . \mathrm{T}=900^{\circ} \mathrm{C}$; Gasification agent: steam 


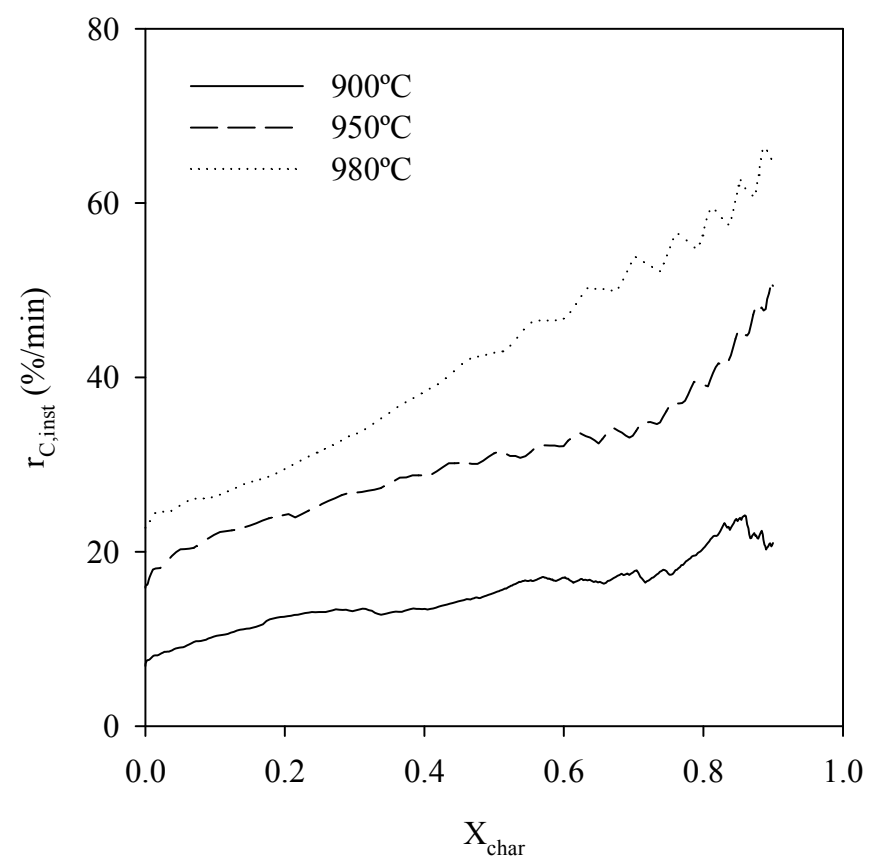

Figure 6. Instantaneous rate of char conversion, $r_{C, \text { inst }}(t)$, as a function of the char conversion at 900,950 and $980^{\circ} \mathrm{C}$ using steam as gasifying agent. Bauxite waste in bed: $400 \mathrm{~g}$. 

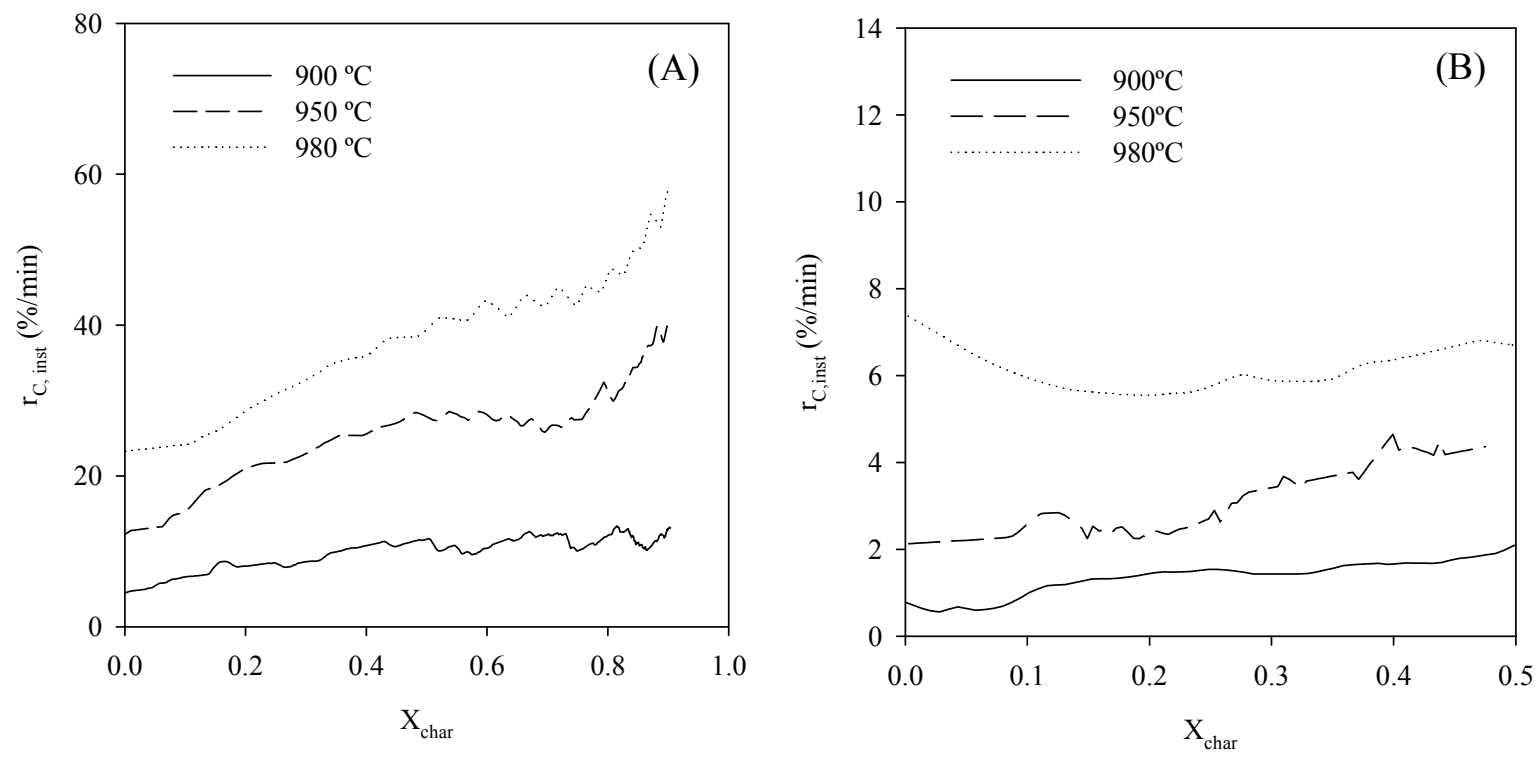

Figure 7. Instantaneous rate of char conversion, $r_{C, \text { inst }}(t)$, as a function of the char conversion at 900,950 and $980^{\circ} \mathrm{C}$ using (A) steam and (B) $\mathrm{CO}_{2}$ as fluidizing agents. Bauxite waste in bed: $200 \mathrm{~g}$. 

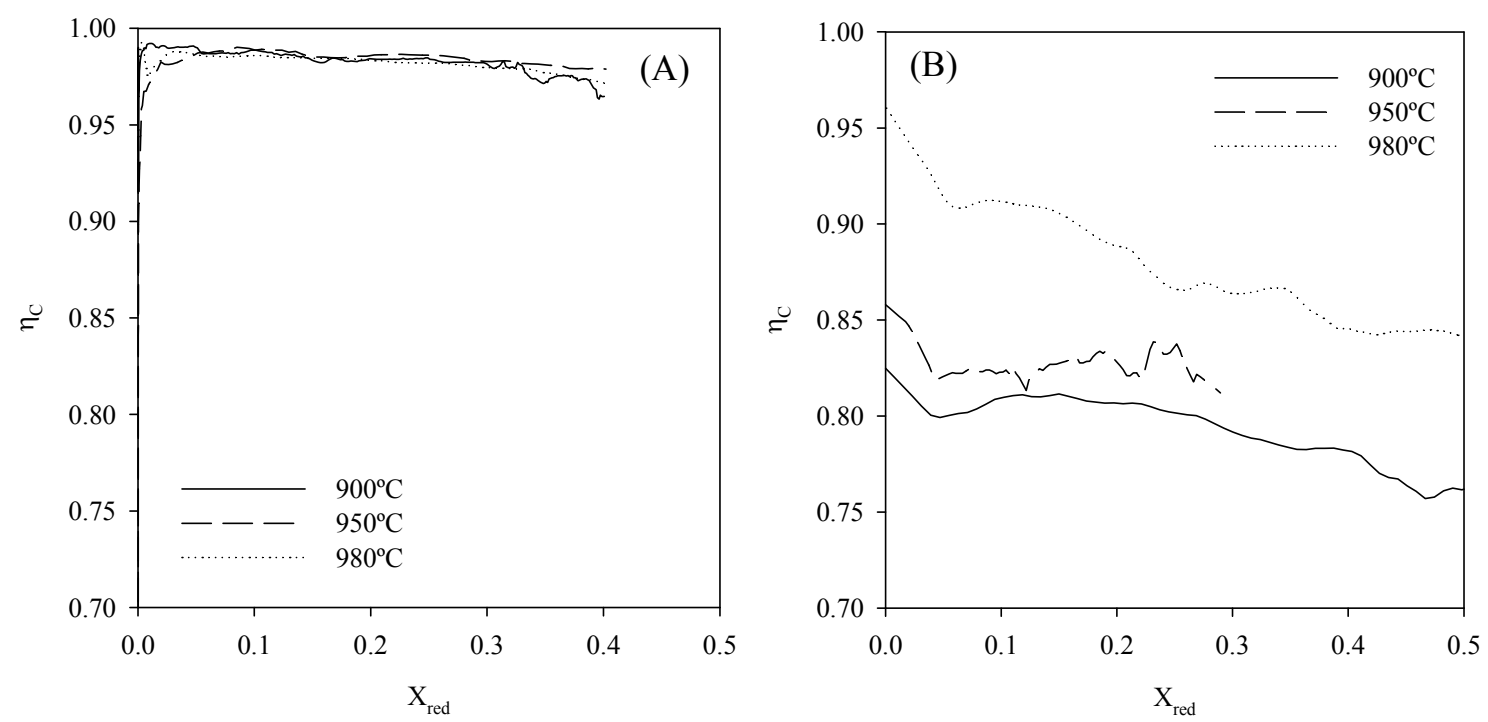

Figure 8. Combustion efficiency, $\eta_{C}$, as a function of the bauxite waste conversion at 900 , 950 and $980^{\circ} \mathrm{C}$ using (A) steam and (B) $\mathrm{CO}_{2}$ as fluidizing agents. Bauxite waste in bed: 200 g. 

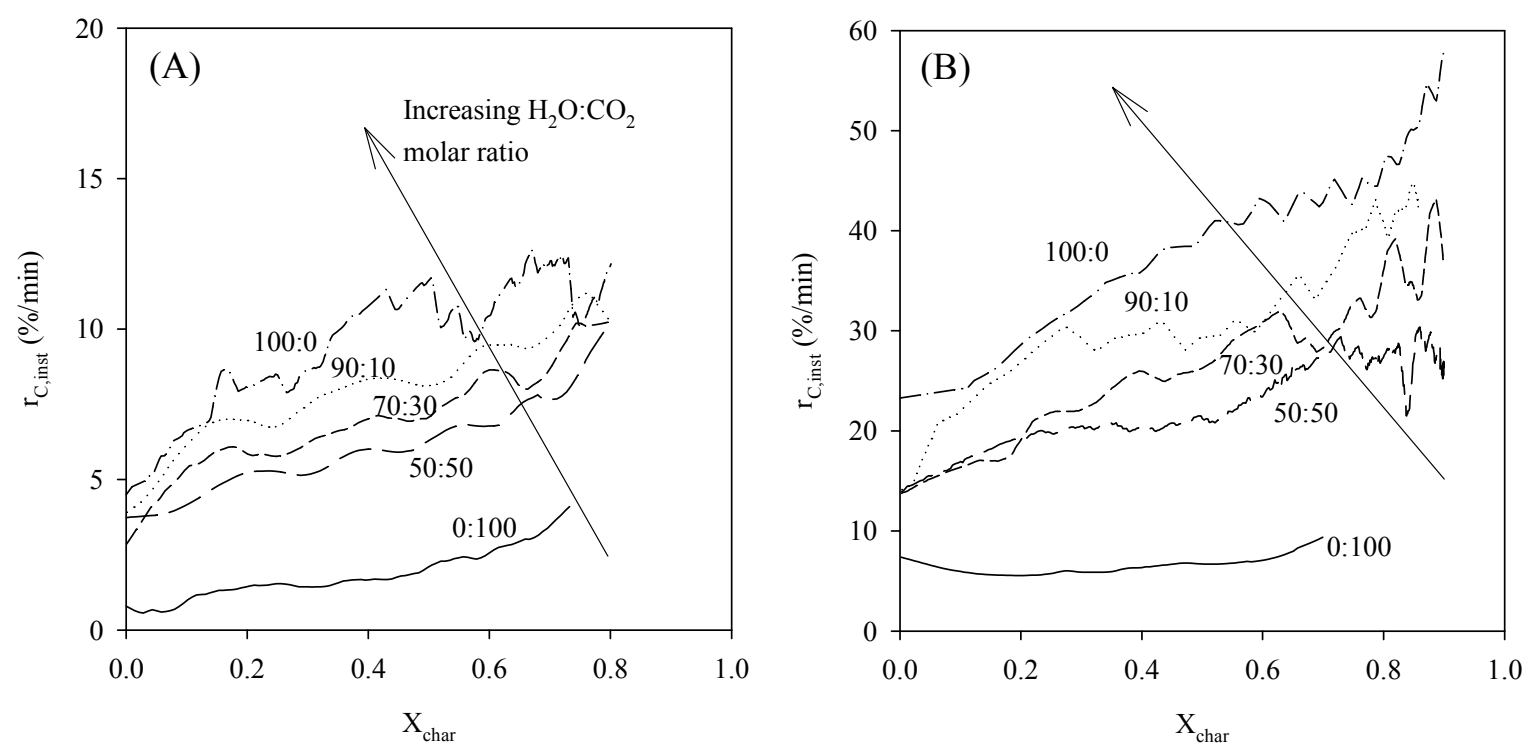

Figure 9. Instantaneous rate of char conversion, $r_{C, \text { inst }}(t)$, as a function of the char conversion using different $\mathrm{H}_{2} \mathrm{O}: \mathrm{CO}_{2}$ molar ratios in the gasifying stream at (A) 900 (B) $980^{\circ} \mathrm{C}$. Bauxite waste in bed: $200 \mathrm{~g}$. 


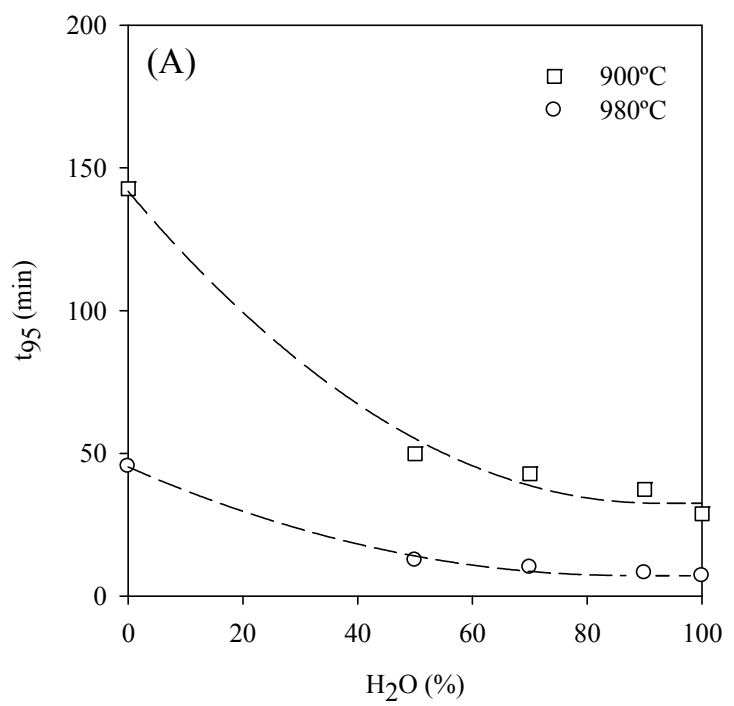

Figure 10. Average values of the residence time to convert $95 \%$ of char, $\left(t_{95}\right)$, using different $\mathrm{H}_{2} \mathrm{O}: \mathrm{CO}_{2}$ molar ratios in the gasifying stream at 900 and $980^{\circ} \mathrm{C}$. Bauxite waste in bed: $200 \mathrm{~g}$. 


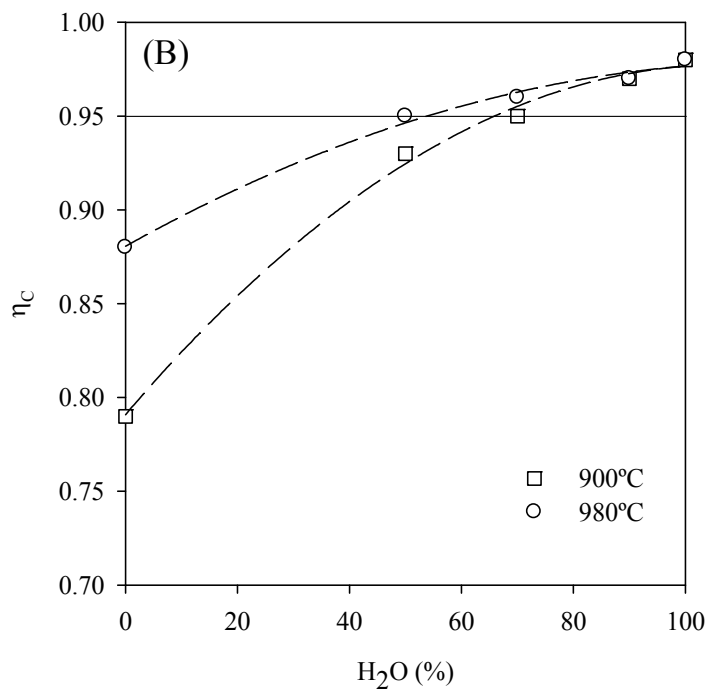

Figure 11. Average values of combustion efficiency using different $\mathrm{H}_{2} \mathrm{O}: \mathrm{CO}_{2}$ molar ratios in the gasifying stream at 900 and $980^{\circ} \mathrm{C}$. Bauxite waste in bed: $200 \mathrm{~g}$. 

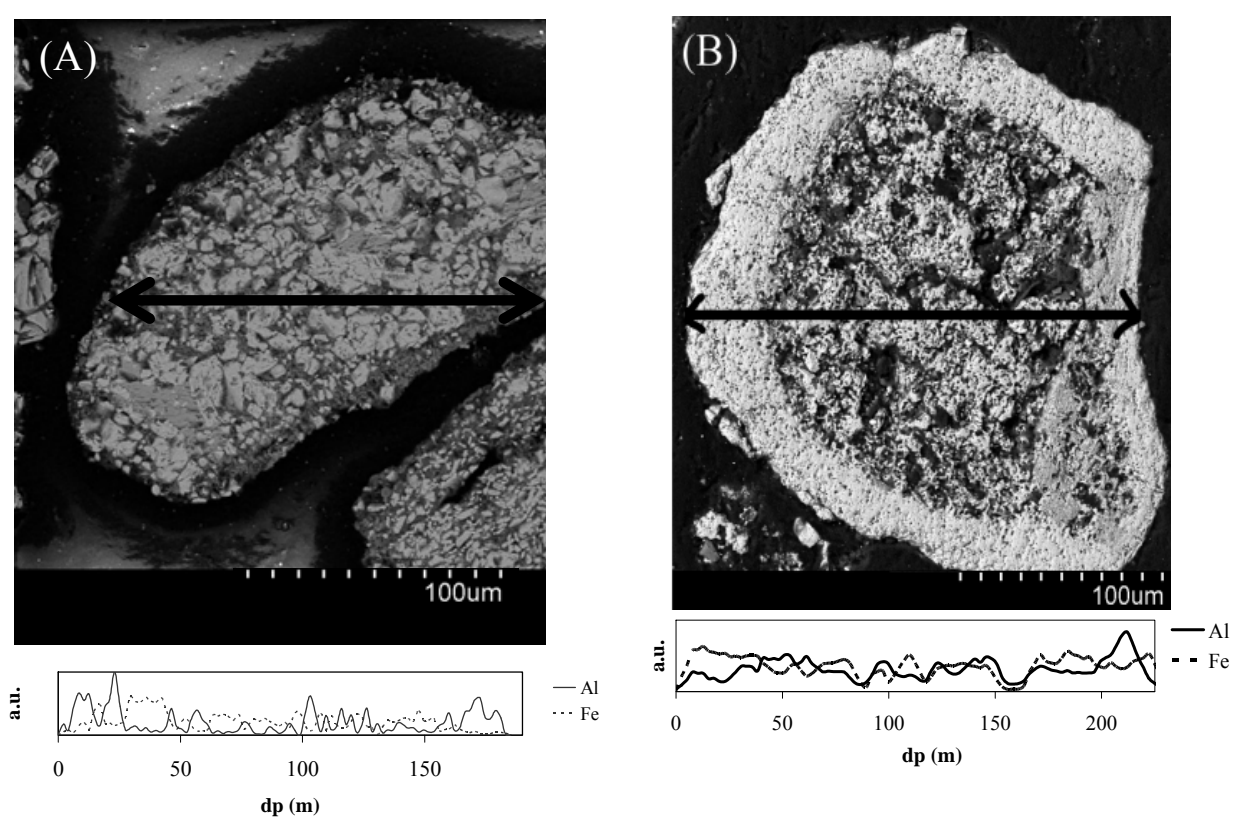

Figure 12. SEM images and EDX profile lines for $\mathrm{Al}$ and $\mathrm{Fe}$ of (A) calcined and (B) used particles after 50 hours of operation in FB with coal char feeding 


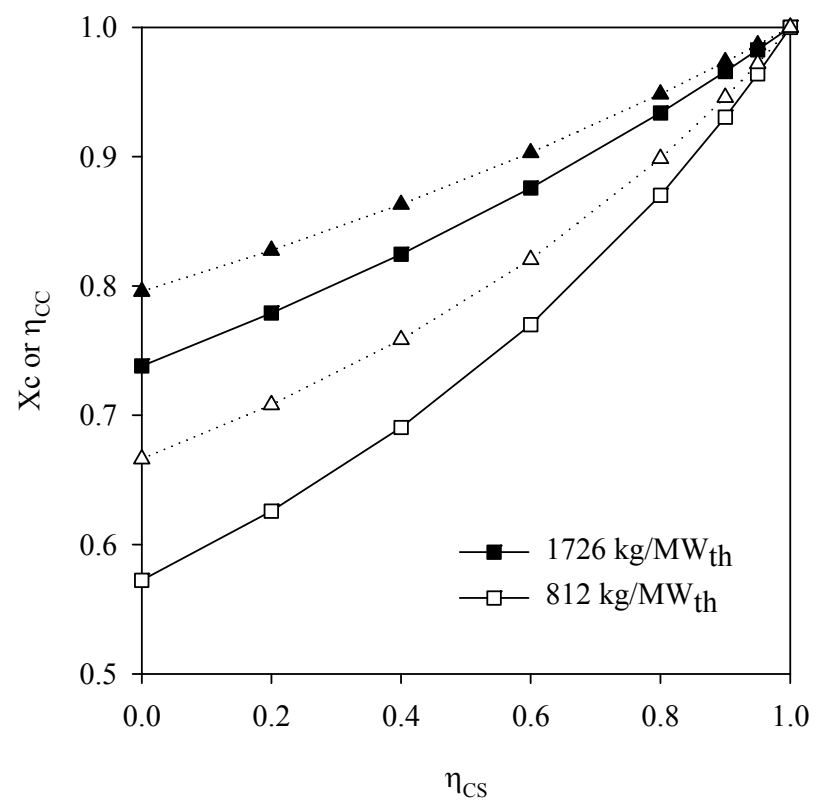

Figure 13. Char conversion by gasification, $X_{c}$ (squares) and carbon capture efficiency, $\eta_{C C}$ (triangles) in the fuel-reactor as a function of the efficiency of the carbon separation system. In all cases, steam was used as gasifying agent at $980^{\circ} \mathrm{C}$. 